\title{
Quality of life data as prognostic indicators of survival in cancer patients: an overview of the literature from 1982 to 2008
} Ali Montazeri ${ }^{1,2}$ Address: ${ }^{1}$ Iranian Institute for Health Sciences Research, ACECR, Tehran, Iran and 2Public Health and Health Policy, Division of Community Based
Sciences, University of Glasgow, Glasgow, UK

Email: Ali Montazeri - montazeri@acecr.ac.ir

Published: 23 December 2009

Health and Quality of Life Outcomes 2009, 7:102 doi:10.1186/1477-7525-7-102

This article is available from: http://www.hqlo.com/content/7/1/102

This is an Open Access article distributed under the terms of the Creative Commons Attribution License (http://creativecommons.org/licenses/by/2.0), which permits unrestricted use, distribution, and reproduction in any medium, provided the original work is properly cited.

\begin{abstract}
Background: Health-related quality of life and survival are two important outcome measures in cancer research and practice. The aim of this paper is to examine the relationship between quality of life data and survival time in cancer patients.
\end{abstract}

Methods: A review was undertaken of all the full publications in the English language biomedical journals between 1982 and 2008. The search was limited to cancer, and included the combination of keywords 'quality of life', 'patient reported-outcomes' 'prognostic', 'predictor', 'predictive' and 'survival' that appeared in the titles of the publications. In addition, each study was examined to ensure that it used multivariate analysis. Purely psychological studies were excluded. A manual search was also performed to include additional papers of potential interest.

Results: A total of 45 I citations were identified in this rapid and systematic review of the literature. Of these, 104 citations on the relationship between quality of life and survival were found to be relevant and were further examined. The findings are summarized under different headings: heterogeneous samples of cancer patients, lung cancer, breast cancer, gastro-oesophageal cancers, colorectal cancer, head and neck cancer, melanoma and other cancers. With few exceptions, the findings showed that quality of life data or some aspects of quality of life measures were significant independent predictors of survival duration. Global quality of life, functioning domains and symptom scores - such as appetite loss, fatigue and pain - were the most important indicators, individually or in combination, for predicting survival times in cancer patients after adjusting for one or more demographic and known clinical prognostic factors.

Conclusion: This review provides evidence for a positive relationship between quality of life data or some quality of life measures and the survival duration of cancer patients. Pre-treatment (baseline) quality of life data appeared to provide the most reliable information for helping clinicians to establish prognostic criteria for treating their cancer patients. It is recommended that future studies should use valid instruments, apply sound methodological approaches and adequate multivariate statistical analyses adjusted for socio-demographic characteristics and known clinical prognostic factors with a satisfactory validation strategy. This strategy is likely to yield more accurate and specific quality of life-related prognostic variables for specific cancers. 


\section{Background}

Health-related quality of life is now considered an important end-point in studies of outcomes in oncology. Studies of quality of life have several benefits when they show evidence that the measurements were conducted and reported appropriately [1]. One benefit is that information obtained from such studies can indicate the directions needed for more efficient treatment of cancer patients. In addition, it has been shown that quality of life assessments in cancer patients may contribute to improved treatment and could even be of prognostic value [2-7].

However, it is believed that health-related quality of life is only a single type of patient-reported outcome. Patientreported outcome is an 'umbrella term' encompassing any outcome reported by a patient himself or herself based on perception of a disease and its treatment, such as healthrelated quality of life, functional well-being and satisfaction [8]. This approach is currently receiving more attention and many believe it could help both physicians and patients, and even family carers to achieve a better understanding of the treatment outcomes of cancer patients and make appropriate decisions.

Using either term - 'patient-reported outcome' or 'healthrelated quality of life' - the evidence compiled suggests that information provided by cancer patients via quality of life measures is very helpful for clinical decision-making and better patient management. For instance, a recent review on health-related quality of life assessment in leukaemia randomised controlled trials showed how quality of life assessments would have added value in supporting clinical decision-making. The review of 3838 leukaemia patients indicated that 'imatinib' greatly improved healthrelated quality of life compared to 'interferon-based' treatment in chronic myeloid leukaemia patients. The review concluded that health-related quality of life assessment is feasible in randomised trials and has the great potential of providing valuable outcomes to further support clinical decision-making [9]. As suggested 'the main advantage of this line of research is that of potentially providing clinicians with a more accurate picture of the patient's prognostic profile, hence possibly further improving accuracy of prognosis and making more tailored treatment decisions' [10].

In addition, since lengthening survival of many or most cancer patients is considered paramount in every effort at treatment, the clinical implications of relationship between quality of life data and survival could be regarded as very important. Thus, many investigators from both clinical oncology and health sciences research have begun demonstrating that health-related quality of life in cancer patients could be associated with survival duration. In fact, this group of investigators has sought to justify the collection of quality of life information, even if only to assess improved survival as the main outcome in cancer care. They believed that quality of life data may not only be helpful in evaluating cancer care outcomes from patients' or family carers' perspectives but may also, like clinical information, be prognostic or predictive of survival duration, thus helping clinicians to reach better decisions on patient management or identify their needs and decide on possible additional interventions, such as referral for counselling or psychosocial help and support. Therefore, biomedical journals have for many years been publishing reports that focus on the relationship between quality of life data and survival duration.

The aim of this review was to examine the literature on the relationship between quality of life data and survival duration since the topic first appeared in English biomedical journals. The intention was to compile the evidence so far obtained, contribute to existing knowledge, and help both researchers and clinicians to achieve a better profile on the topic, and consequently aid in improving the quality of life of cancer patients.

\section{Methods \\ Search engines and time period}

A literature search was carried out using MEDLINE, EMBASE, the Science Citation Index (ISI), the Cumulative Index to Nursing and Allied Health Literature (CINAHL), the PsycINFO, the Allied and Complementary Medicine (AMED) and Global Health databases to assess the existing knowledge about the relationship between quality of life data as 'prognostic' or 'predictive' indicators and survival in cancer patients. The aim was to review all full publications that appeared in English language biomedical journals between 1982 and 2008. The year 1982 was chosen because the first study on the relationship between survival and quality of life data was published in that year.

\section{Definitions}

- Health-related quality of life was defined as an individual's perceived physical, mental and social health status affected by cancer diagnosis or treatment. This article uses the terms 'health-related quality of life' and 'quality of life' interchangeably.

- Health-related quality of life measures (instruments, questionnaires) were defined as well-established questionnaires that measure individuals' perceptions of their own physical, mental and social health status, or some aspects of their health status resulting from cancer and its treatment. 
- Health-related quality of life data were defined as the data collected using valid generic or specific health-related quality of life measures.

- Predictive or prognostic indicators were defined as any independent variables (e.g. health-related quality of life parameters) that can be used to estimate the chance of a given outcome (e.g. survival duration).

\section{Search strategy}

The search strategy was limited to cancer and included the combination of keywords 'quality of life', 'patientreported outcomes' 'prognostic', 'predictor', 'predictive', and 'survival' in the titles of publications. This provided the initial database for the review. A manual search also was performed to include possible additional papers.

\section{Inclusion and exclusion criteria}

In addition to publication titles, the literature was examined to ensure that the study used a quality of life instrument or measured quality of life using proxy indicators, and applied multivariate analyses for survival adjusted for one or more known clinical prognostic indicators. Purely psychological studies were excluded. These were defined as studies limited to the relationship between one or more psychological variables, such as fighting spirit, cancer personality, coping styles, hostility, etc. and survival duration.

\section{Data synthesis}

Data obtained from each single study were synthesized by providing descriptive tables reporting authors' names, publication year, study sample, type of cancer (where relevant data were available), instrument used to measure quality of life, and the main findings or conclusions. The findings were then sorted and presented chronologically.

\section{Results}

\section{Statistics}

In total, 451 citations were identified in this systematic review of the literature. After exclusion of duplicates, the abstracts of all citations were reviewed. Of these, 104 citations concerning the relationship between quality of life and survival were found to be relevant and were further examined (Figure 1). Here, the major findings are summarized and presented under the following headings.

\section{Early pivotal publications [1982-1989]}

During the 1980s, a few papers reported positive relationships between some psychosocial and quality of life parameters and survival time in cancer patients. The first paper on this relationship was published in 1982. In that paper the existing records of 651 patients with bronchogenic carcinoma were assessed to determine the relationship between survival and four 'non-anatomical' prognostic indicators: symptomatic history, performance status, weight loss and age. Adjusting for stage, histological factors and treatment, the analysis showed that weight loss and performance status were significantly associated with survival [11]. In 1985, Cassileth et al. studied 359 cancer patients and found no association between social and psychological factors and duration of survival or time to relapse. They did not collect data on health-related quality of life but concluded that, although these factors may contribute to the initiation of morbidity, the biology of the disease appears to predominate, overriding the potential influence of life-style and psychosocial variables once the disease process has been established [12]. The third paper on the topic appeared in 1987. This paper compared quality of life during chemotherapy for advanced breast cancer between patients receiving intermittent and continuous treatment strategies. The findings indicated that changes in the quality of life index, measured by a series of Linear Analog Self Assessment (LASA) scales for physical wellbeing, mood, pain and appetite, were independent prognostic indicators of subsequent survival [13]. Kaasa et al. also published a paper on the topic in 1989, in which for inoperable non-small-cell lung cancer they showed that general symptoms and psychological well-being were the best predictors of survival duration [14].

\section{Heterogeneous sample of cancer patients}

Some studies included a heterogeneous sample of cancer populations [15-21]. Global quality of life and physical, social, emotional and cognitive functioning were found to be independent prognostic indicators of survival.

A number of studies showed that global quality of life or global health status was associated with survival time [1719]. In a study of 253 patients with different cancer diagnoses, Ringdal et al. [16] performed Cox regression analysis adjusted for clinical, demographic and psychosocial factors. They found that physical functioning was an independent predictor of survival time, but psychosocial covariates were not. The results are shown in Table 1.

\section{Lung cancer}

Relatively more studies have examined the relationship between quality of life data and survival in lung cancer patients [11,14,22-45]. These studies included either a sample of both small-cell and non-small-cell lung cancer patients, or mostly advanced non-small-cell patients. Two of these 25 studies reported that the overall quality of life score was not a predictor of survival $[28,44]$. In most instances, baseline overall or global quality of life scores were independent prognostic indicators of survival duration. A clinical trial using FACT-L showed that a higher baseline physical well-being score was not only associated with a better response to treatment (odds ratio $=1.09$; $\mathrm{P}<$ 0.001 ) and lower risk of death (risk ratio 0.95; $\mathrm{P}<0.001$ ), 


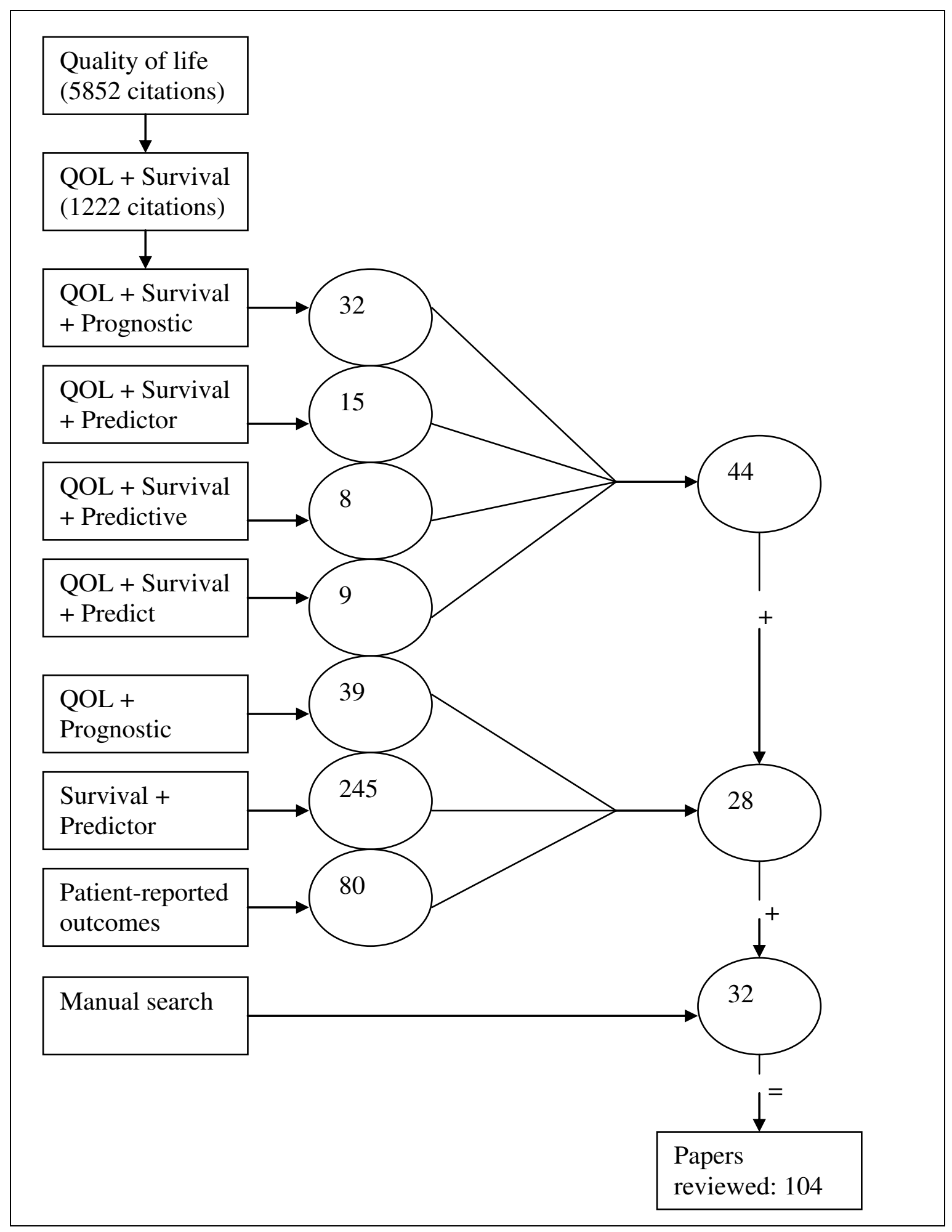

Figure I

A schematic picture of the search strategy limited to cancer patients with indicated keywords in titles of publications (numbers are frequency of citations). 
Table I: Studies on relationship between quality of life data and survival in heterogeneous sample of cancer patients

\begin{tabular}{|c|c|c|c|c|}
\hline Author(s) & Year & Sample & HRQOL measure(s) & Results* \\
\hline Degner and Sloan [15] & 1995 & $\begin{array}{l}435 \text { ambulatory heterogeneous } \\
\text { sample of cancer patients } \\
\text { (including } 82 \text { lung cancer) }\end{array}$ & SDS & $\begin{array}{l}\text { The single measure of symptom distress } \\
\text { was a significant predictor of survival in } \\
\text { lung cancer. }\end{array}$ \\
\hline Ringdal et al. [16] & 1996 & $\begin{array}{l}253 \text { heterogeneous sample of cancer } \\
\text { patients }\end{array}$ & $\begin{array}{l}\text { Physical functioning + } \\
\text { psychosocial variables }\end{array}$ & $\begin{array}{l}\text { Physical functioning was prognostic factor } \\
\text { of survival but psychosocial covariates } \\
\text { were not. }\end{array}$ \\
\hline Tamburini et al. [I7] & 1996 & I00 terminal cancer patients & TIQ & $\begin{array}{l}\text { Confusion, cognitive status and global } \\
\text { health status were independent } \\
\text { prognostic of survival. }\end{array}$ \\
\hline Coates et al. [18] & 1997 & 735 advanced malignancies & EORTC QLQ-C30 & $\begin{array}{l}\text { Global QOL and social functioning were } \\
\text { significantly predictive of survival among } \\
\text { solid tumor patients, metastatic site. }\end{array}$ \\
\hline Dancey et al. [19] & 1997 & $\begin{array}{l}474 \text { heterogeneous population of } \\
\text { cancer patients }\end{array}$ & EORTC QLQ-C30 & $\begin{array}{l}\text { Global QOL was significantly associated } \\
\text { with survival. }\end{array}$ \\
\hline Chang et al. [20] & 1998 & $\begin{array}{l}218 \text { cancers patients } \\
\text { (colon, breast, ovary or prostate) }\end{array}$ & MSAS & $\begin{array}{l}\text { Physical symptom subscale score } \\
\text { significantly predicted survival. }\end{array}$ \\
\hline Lam et al. [2I] & 2007 & 170 advanced cancer & HDS + ESAS + McGill QOL & $\begin{array}{l}\text { ESAS score was independent prognostic } \\
\text { factor for survival. }\end{array}$ \\
\hline
\end{tabular}

\footnotetext{
Abbreviations: EORTC QLQ-C30: European Organization for Research and Treatment of Cancer Quality of Life Core Questionnaire; ESAS: Edmonton Symptom Assessment System; HDS: Hamilton Depression Scale; McGill QOL: McGill quality of Life-single item; MSAS: Memorial Symptom Assessment Scale; QOL: quality of life; SDS: Symptom Distress Scale; TIQ: Therapy Impact Questionnaire.

* All results obtained from multivariate analyses after controlling for one or more demographic and known biomedical prognostic factors.
}

but also showed that the patient-reported health change during chemotherapy was a significant predictor of clinical outcomes [35]. In contrast, a small-scale study ( $\mathrm{n}=30$, non-small cell lung cancer) using a similar instrument showed no association between the change in quality of life score and survival [31]. In addition, most studies have shown that pain and appetite loss are independent determinants of overall survival. One found that a 40-point increase in the pain subscale of the EORTC QLQ-C30 was associated with a $27 \%$ increase in the rate-of-dying hazard [27]. Similarly, Efficace et al. found that a 10-point worsening in the pain and dysphagia scores in a sample of 391 advanced non-small-cell lung cancer patients resulted in a hazard ratio of 1.11 and 1.12 , equivalent to $11 \%$ and $12 \%$ increases in the likelihood of death, respectively [41]. However, psychological distress in lung cancer patients was also associated with survival duration. A study of 133 lung cancer patients using the Self-rating Depression Scale (SDS) indicated that item 19 ("I feel that others would be better off if I were dead") emerged as the most significant predictor of survival duration [26]. Table 2 summarizes the results.

\section{Breast cancer}

Studies that examined the relationship between quality of life data and survival in breast cancer patients are pre- sented in Table 3[13,46-63]. Some showed that baseline quality of life predicts survival in advanced breast cancer, but not in early stages of disease [51]. Two recently published papers also confirmed that baseline quality of life was not a prognostic indicator in non-metastatic breast cancer patients. One of these, using Cox survival analysis, indicated that neither health-related quality of life nor psychological status at diagnosis or one year later was associated with medical outcome in women with earlystage breast cancer [59]. The other, on a sample of 448 locally advanced (non-metastatic) breast cancer patients, showed that baseline health-related quality of life parameters had no prognostic value [57]. The latter study reported that the final multivariate model retained inflammatory breast cancer as the only factor predicting overall survival, with a hazard ratio of 1.37 (95\% CI = 1.02-1.84). However, a study using the Daily Diary Card to measure quality of life in advanced breast cancer showed that the instrument afforded accurate prognosis of the subsequent response to treatment and survival duration [47]. Similarly, Seidman et al. [48] evaluated quality of life in two phase-II clinical trials for metastatic breast cancer and found that the baseline scores of two validated quality of life instruments independently predicted overall survival. In addition, some studies have demonstrated that certain aspects of quality of life data, 
Table 2: Studies on relationship between quality of life data and survival in patients with lung cancer

\begin{tabular}{lclll}
\hline Author(s) & Year & Sample & HRQOL measure(s) \\
\hline Pater and Loeb [II] & 1982 & $65 \mathrm{I}$ bronchogenic carcinoma & $\begin{array}{l}\text { Symptomatic history, performance } \\
\text { status, weight loss and age }\end{array}$ & $\begin{array}{l}\text { Weight loss and performance status } \\
\text { were significantly affected survival. }\end{array}$ \\
\hline Kaasa et al. [14] & 1989 & $\begin{array}{l}102 \text { inoperable non-small-cell, } \\
\text { limited disease }\end{array}$ & $\begin{array}{l}\text { Psychological well-being + disease- } \\
\text { related symptoms + personal } \\
\text { functioning + everyday activity }\end{array}$ & $\begin{array}{l}\text { Well-being were the best predictive } \\
\text { value for survival. }\end{array}$
\end{tabular}

Ganz et al. [22] 1991 $\begin{aligned} & 40 \text { advanced metastatic lung } \\ & \text { cancer }\end{aligned} \quad$ FLI-C

A statistically significant relationship was observed between initial patient-rated QOL and subsequent survival.

\begin{tabular}{llll}
\hline Ruckdeschel et al. [23] & 1994 & F38 lung cancer & FLI-C \\
\hline Loprinzi et al. [24] & 1994 & $\begin{array}{l}\text { I,II5 advanced colorectal or } \\
\text { lung cancers }\end{array}$ & $\begin{array}{l}\text { A designed patient-completed } \\
\text { questionnaire }\end{array}$
\end{tabular}

Total FLI-C score was significant predictor of survival.

Patients' assessment of their own performance status and nutritional factors such as appetite, caloric intake, or overall food intake were prognostic of survival.

\begin{tabular}{|c|c|c|c|c|}
\hline Buccheri et al. [25] & 1995 & I 28 Lung cancer & $\mathrm{TIQ}$ & $\begin{array}{l}\text { The self-estimated difficulty at work } \\
\text { and doing housework were } \\
\text { significant independent prognostic } \\
\text { determinants of survival. }\end{array}$ \\
\hline Buccheri et al. [26] & 1998 & I33 Lung cancer & SDS & $\begin{array}{l}\text { Depression was associated with } \\
\text { survival. Diverse SDS subscales were } \\
\text { associated with survival. }\end{array}$ \\
\hline
\end{tabular}

\begin{tabular}{|c|c|c|c|c|}
\hline Herndon et al. [27] & 1999 & $\begin{array}{l}206 \text { advanced non-small-cell } \\
\text { lung cancer }\end{array}$ & $\begin{array}{l}\text { EORTC QLQ-C30 + Duke-UNC } \\
\text { Social Support Scale }\end{array}$ & $\begin{array}{l}\text { Pain was a significant predictor of } \\
\text { survival but overall QOL was not. }\end{array}$ \\
\hline Langendijk et al. [28] & 2000 & $\begin{array}{l}\text { I } 98 \text { inoperable non-small-cell } \\
\text { lung cancer }\end{array}$ & EORTC QLQ-C30 & $\begin{array}{l}\text { Global QOL was a strong prognostic } \\
\text { factor of survival. }\end{array}$ \\
\hline Burrows et al. [29] & 2000 & $\begin{array}{l}85 \text { recurrent symptomatic } \\
\text { malignant pleural effusions }\end{array}$ & KPS & $\begin{array}{l}\text { Only the KPS score (score } \geq 70 \text { ) at } \\
\text { the time of thoracoscopy was } \\
\text { predictive of survival. Pleural fluid } \\
\text { pH, pleural fluid glucose, and EPC } \\
\text { scores were not as reliable as } \\
\text { initially reported. }\end{array}$ \\
\hline Montazeri et al. [30] & 2001 & $\begin{array}{l}\text { I } 29 \text { lung cancer } \\
\text { (small and non-small-cell) }\end{array}$ & $\begin{array}{l}\text { NHP + EORTC QLQ-C30 + } \\
\text { EORTC QLQ-LCI3 }\end{array}$ & $\begin{array}{l}\text { Baseline global QOL was most } \\
\text { significant predictor of the length of } \\
\text { survival. }\end{array}$ \\
\hline Auchter et al. [3I] & 2001 & 30 non-small cell lung cancer & FACT-L (TOI) & $\begin{array}{l}\text { The change in TOI score was not } \\
\text { associated with survival. A trend was } \\
\text { noted for shorter survival with the } \\
\text { largest negative change in TOI score. }\end{array}$ \\
\hline Moinpour et al. [32] & 2002 & 222 advanced non-small-cell & FACT-L & $\begin{array}{l}\text { Total FACT-L score was predictor } \\
\text { of survival. }\end{array}$ \\
\hline Nakahara et al. [33] & 2002 & $\begin{array}{l}\text { I79 advanced small- and non- } \\
\text { small cell lung cancer }\end{array}$ & $\begin{array}{l}\text { Tokyo University Egogram } \\
\text { (measure for mental state) }\end{array}$ & $\begin{array}{l}\text { Mental state was prognostic of } \\
\text { survival. }\end{array}$ \\
\hline
\end{tabular}


Table 2: Studies on relationship between quality of life data and survival in patients with lung cancer (Continued)

\begin{tabular}{|c|c|c|c|c|}
\hline Naughton et al. [34] & 2002 & 70 small-cell lung cancer & $\begin{array}{l}\text { EORTC QLQ-C30 + CES-D + } \\
\text { MOS Social Support } \\
\text { Questionnaire + a sleep quality } \\
\text { scale }\end{array}$ & $\begin{array}{l}\text { Higher depressive symptoms were } \\
\text { borderline significant in predicting } \\
\text { decreased survival. }\end{array}$ \\
\hline Eton et al. [35] & 2003 & $\begin{array}{l}573 \text { advanced non-small-cell } \\
\text { lung cancer }\end{array}$ & FACT-L + TOI & $\begin{array}{l}\text { Baseline physical well-being and TOI } \\
\text { scores predicted either survival } \\
\text { duration or disease progression } \\
\text { respectively. }\end{array}$ \\
\hline Dharma-Wardene et al. [36] & 2004 & 44 advanced lung cancer & FACT-G & $\begin{array}{l}\text { Baseline FACT-G total score was } \\
\text { significantly associated with survival. }\end{array}$ \\
\hline Nowak et al. [37] & 2004 & 53 pleural mesothelomia & $\begin{array}{l}\text { EORTC QLQ-C30 + EORTC } \\
\text { QLQ-LCI3 }\end{array}$ & $\begin{array}{l}\text { Functional domains and symptom } \\
\text { scales (fatigue and pain) } \\
\text { demonstrated predictive validity for } \\
\text { survival. }\end{array}$ \\
\hline Maione et al. [38] & 2005 & $\begin{array}{l}566 \text { advanced non-small-cell } \\
\text { lung cancer }\end{array}$ & $\begin{array}{l}\text { ADL + IADL + EORTC QOL-C30 } \\
\text { (global QOL) }\end{array}$ & $\begin{array}{l}\text { Baseline global QOL and IADL were } \\
\text { significant prognostic factors for } \\
\text { overall survival. }\end{array}$ \\
\hline Brown et al. [39] & 2005 & 273 non-small-cell lung cancer & $\begin{array}{l}\text { EORTC QLQ-C30 + EORTC } \\
\text { QLQ-LCI7 + DDC }\end{array}$ & $\begin{array}{l}\text { Global QOL, role functioning, } \\
\text { fatigue, appetite loss and } \\
\text { constipation were prognostic } \\
\text { indicators of survival. }\end{array}$ \\
\hline Martins et al. [40] & 2005 & $\begin{array}{l}41 \text { locally advanced or } \\
\text { metastatic lung cancer }\end{array}$ & LCSS & $\begin{array}{l}\text { Patients' scores on the LCSS } \\
\text { appetite and fatigue subscales were } \\
\text { independent predictors of survival. }\end{array}$ \\
\hline Efficace et al. [4I] & 2006 & $\begin{array}{l}391 \text { advanced non-small-cell } \\
\text { lung cancer }\end{array}$ & $\begin{array}{l}\text { EORTC QLQ-C30 + EORTC } \\
\text { QLQ-LCI3 }\end{array}$ & $\begin{array}{l}\text { Pain, and dysphagia were significant } \\
\text { prognostic factors for survival. }\end{array}$ \\
\hline Sundstrom et al. [42] & 2006 & $\begin{array}{l}30 \text { I stag III non-small-cell lung } \\
\text { cancer }\end{array}$ & EORTC QLQ-C30 & $\begin{array}{l}\text { Appetite loss was the most } \\
\text { significant prognostic factor of } \\
\text { survival. }\end{array}$ \\
\hline Bottomley et al. [43] & 2007 & $\begin{array}{l}250 \text { malignant pleural } \\
\text { mesothelioma }\end{array}$ & $\begin{array}{l}\text { EORTC QLQ-C30 + EORTC } \\
\text { QLQ-LCI3 }\end{array}$ & $\begin{array}{l}\text { Pain, and appetite loss were } \\
\text { independent prognostic indicators of } \\
\text { survival. }\end{array}$ \\
\hline Fielding and Wong [44] & 2007 & 534 liver and lung cancers & FACT-G & $\begin{array}{l}\text { Global QOL scores did not predict } \\
\text { survival in liver and lung cancer. } \\
\text { Physical well-being and appetite } \\
\text { predicted survival in lung cancer. }\end{array}$ \\
\hline Jacot et al. [45] & 2008 & 301 non-small-cell lung cancer & LCSS & $\begin{array}{l}\text { Pretreatment LCSS global symptoms } \\
\text { score was independent determinant } \\
\text { of overall survival. }\end{array}$ \\
\hline
\end{tabular}

Abbreviations: CES-D: Centre for Epidemiologic Studies-Depression Scale; DDC: Daily Diary Card; EORTC QLQ-C30: European Organization for Research and Treatment of Cancer Quality of Life Core Questionnaire; EORTC QLQ-LCI3 (or QLQ LCI7): EORTC Lung Cancer specific Quality of Life Questionnaire (previously containing I 7items); FACT-G: Functional Assessment of Cancer Therapy-General module; FACT-L: Functional Assessment of Cancer Therapy-Lung module; FLI-C: Functional Living Index-Cancer; IADL: Instrumental Activities of Daily Living; KPS: Karnofsky Performance Status; LCSS: Lung Cancer Symptoms Scale; MOS: Medical Outcomes Study; ADL: Activities of Daily Living; NHP: Nottingham Health Profile; QOL: quality of life; SDS: Self-rating Depression Scale; TIQ: Therapy Impact Questionnaire; TOI: Trial Outcome Index.

* All results obtained from multivariate analyses after controlling for one or more demographic and known biomedical prognostic factors. 
Table 3: Studies on relationship between quality of life data and survival in patients with breast cancer

\begin{tabular}{lllll}
\hline Author(s) & Year & Sample & HRQOL measure(s)* & Results* \\
\hline Coates et al. [13] & 1987 & 226 advanced breast cancer & $\begin{array}{l}\text { LASA scores for physical well-being + } \\
\text { mood, pain, and appetite } \\
\text { (as QOL index) }\end{array}$ & $\begin{array}{l}\text { Changes in QOL scores were } \\
\text { independent prognostic of survival. }\end{array}$
\end{tabular}

Coates et al. [46] $\quad 1992 \quad 226$ advanced breast cancer $\quad$ LASA scores for physical well-being + mood, nausea, vomiting, and appetite (as QOL index)

Fraser et al. [47] $\quad 1993 \quad 60$ advanced breast cancer $\quad$ DDC + LASA + NHP
Both QOL index and physical well-being were independent prognostic factors of survival.

The DDC provided accurate prognostic data regarding subsequent response and survival.

\begin{tabular}{|c|c|c|c|c|}
\hline Seidman et al. [48] & 1995 & 40 advanced breast cancer & $\begin{array}{l}\text { MSAS + MSAS-GDI + FLI-C + RMHI + } \\
\text { BPI + MPAC }\end{array}$ & $\begin{array}{l}\text { Baseline global QOL and distress index } \\
\text { scores independently predicted the } \\
\text { overall survival. }\end{array}$ \\
\hline Tross et al. [49] & 1996 & $\begin{array}{l}280 \text { early stage breast } \\
\text { cancer }\end{array}$ & SCL-90-R & $\begin{array}{l}\text { No significant predictive effect of the } \\
\text { level of depression on length of disease- } \\
\text { free and overall survival observed. }\end{array}$ \\
\hline Watson et al. [50] & 1999 & $\begin{array}{l}578 \text { early stage breast } \\
\text { cancer }\end{array}$ & $\mathrm{MAC}+\mathrm{CECS}+\mathrm{HADS}$ & $\begin{array}{l}\text { Depression score of the HADS and } \\
\text { helplessness and hopelessness category } \\
\text { of the MAC had determinant effect on } \\
\text { survival. }\end{array}$ \\
\hline
\end{tabular}

\begin{tabular}{llll}
\hline Coats et al. [5I] & 2000 & $\begin{array}{l}227 \text { metastatic and early } \\
\text { stage breast cancer }\end{array}$ & $\begin{array}{l}\text { Physical well-being + mood, appetite, } \\
\text { and coping (as QOL index) }\end{array}$
\end{tabular}

Disease-free survival was not significantly predicted by QOL scores at baseline or by changes in QOL scores. After relapse QOL scores were predictive for subsequent survival.

Kramer et al. [52] $\quad 2000 \quad 187$ advanced breast cancer $\quad$ EORTC QLQ-C30

Pain was prognostic for survival. However, fatigue and emotional functioning were significant in backward selection model.

\begin{tabular}{lll}
\hline Shimozuma et al. [53] 2000 & $\begin{array}{l}47 \text { advanced or end stage } \\
\text { breast cancer }\end{array}$
\end{tabular}

Physical aspects of QOL were significantly related to survival. The change in scores of both overall QOL and the physical aspects of QOL were also significant predictors of survival.

\begin{tabular}{|c|c|c|c|c|}
\hline Butow et al. [54] & 2000 & 99 metastatic breast cancer & $\begin{array}{l}\text { Cognitive appraisal of threat }+ \text { coping }+ \\
\text { psychological adjustment }+ \text { perceived } \\
\text { aim of treatment }+ \text { social support }+ \\
\text { QOL }\end{array}$ & $\begin{array}{l}\text { Minimization was associated with longer } \\
\text { survival while a better appetite predicted } \\
\text { shorter duration of survival. }\end{array}$ \\
\hline
\end{tabular}

Luoma et al. [55] 2003279 advanced breast cancer $\quad$ EORTC QLQ-C30

Baseline severe pain was predictive for a shorter overall survival. QOL scores had no great importance in predicting primary clinical endpoints such as time to progression or overall survival.

\begin{tabular}{lllll}
\hline Winer et al. [56] & 2004 & 474 metastatic breast cancer & FLI-C + SDS & $\begin{array}{l}\text { Global QOL and symptom distress } \\
\text { scores were prognostic for survival. }\end{array}$ \\
\hline Efficace et al. [57] & 2004 & $\begin{array}{l}448 \text { nonmetastatic breast } \\
\text { cancer }\end{array}$ & EORTC QLQ-C30 & $\begin{array}{l}\text { Baseline QOL had no prognostic value in } \\
\text { nonmetastatic breast cancer. }\end{array}$ \\
\hline Efficace et al. [58] & 2004 & 275 matastatic breast cancer & EORTC QLQ-C30 + QLQ-BR23 & $\begin{array}{l}\text { Loss of appetite was a significant } \\
\text { prognostic factor for survival. }\end{array}$
\end{tabular}


Table 3: Studies on relationship between quality of life data and survival in patients with breast cancer (Continued)

\begin{tabular}{lllll}
\hline Goodwin et al. [59] & 2004 & $\begin{array}{l}397 \text { early stage breast } \\
\text { cancer }\end{array}$ & $\begin{array}{l}\text { EORTC QLQ-C30 + POMS + PAIS + } \\
\text { IES + MACS +ACS + CECS }\end{array}$ & $\begin{array}{l}\text { QOL and psychological status at } \\
\text { diagnosis and I year later were not } \\
\text { associated with medical outcome. }\end{array}$ \\
\hline Watson et al. [60] & 2005 & $\begin{array}{l}578 \text { early stage breast } \\
\text { cancer }\end{array}$ & MAC + HADS & $\begin{array}{l}\text { Helplessness/hopelessness was a } \\
\text { significant predictor of disease-free } \\
\text { survival but depression was not. }\end{array}$ \\
\hline Lehto et al. [61] & 2006 & 72 localized breast cancer & $\begin{array}{l}\text { Coping + emotional expression + } \\
\text { perceived support + life stresses + QOL }\end{array}$ & $\begin{array}{l}\text { Longer survival was predicted by a } \\
\text { minimizing-related coping while shorter } \\
\text { survival was predicted by anti- } \\
\text { emotionality, escape coping, and high } \\
\text { level of perceived support. }\end{array}$ \\
\hline Gupta et al. [62] & 2007 & 251 breast carcinoma & Ferrans and Powers QLI & $\begin{array}{l}\text { Baseline patient satisfaction with health } \\
\text { and physical functioning and overall } \\
\text { HRQOL were significant prognostic of } \\
\text { survival. }\end{array}$ \\
\hline Groenvold et al. [63] 2007 & 1588 breast cancer & EORTC QLQ-C30 + HADS & $\begin{array}{l}\text { Emotional functioning was predicted } \\
\text { overall survival and fatigue was } \\
\text { independent predictor of recurrence- } \\
\text { free survival. }\end{array}$
\end{tabular}

\begin{abstract}
Abbreviations: ACS: Adjustment to Cancer Scale; BPI: Brief Pain Inventory; CECS: Courtauld Emotional Control Scale; DDC: Daily Dairy Card; EORTC QLQ-C30: European Organization for Research and Treatment of Cancer Quality of Life Core Questionnaire; FLIC: Functional Living Index-Cancer; HADS: Hospital Anxiety and Depression Scale; IES: Impact of Events Scale; LASA: Linear Analog Self Assessment; MAC: Mental Adjustment to Cancer Scale; MPAC: Memorial Pain Assessment Card; MSAS: Memorial Symptom Assessment Scale; MSAS-GDI: Memorial Symptom Assessment Scale-Global Distress Index; NHP: Nottingham Health Profile; PAIS: Psychological Adjustment to Illness Scale; POMS: Profile of Mood States; QLI: Quality of Life Index; QOL: quality of life; QOL-ACD: Quality of Life Questionnaire for Cancer Patients Treated with Anticancer Drugs; RMHI: Rand Mental Health Inventory; SCL-90-R: Symptom Check List-90 items-Revised; SDS: Symptom Distress Scale.

* All results obtained from multivariate analyses after controlling for one or more demographic and known biomedical prognostic factors.
\end{abstract}

including physical health [46], pain $[52,55]$ and loss of appetite [58], were significant prognostic indicators of survival in women with advanced breast cancer. One study also demonstrated that baseline physical aspects of quality of life and its changes were related to survival, but psychological and social aspects were not [53].

\section{Gastro-oesophageal cancers}

The findings are summarized in Table 4[64-71]. Studies have shown that physical functioning was an important prognostic indicator for survival in this group of cancer patients. Blazeby et al. [65], using the EORTC core and specific quality of life measures in their study of 89 oesophageal cancer patients, showed that a 10-point increase in the physical functioning score corresponded to a $12 \%$ reduction in the likelihood of death at any given time (95\% CI $=4-18 \%)$. Recent studies using the EORTC QLQ-C30 and QLQ-OES18 found that in addition to physical functioning, symptoms such as fatigue, reflux and appetite loss were also independent predictors of survival duration in patients with either gastric or oesophageal cancers $[69,70]$. Using the same instrument (EORTC QLQ-C30), a large study of 1080 locally-advanced or metastatic oesophago-gastric cancer patients indicated that the global quality of life during pre-treatment was a pre- dictor of survival duration [67]. However, a study of 185 localized oesophageal cancer patients reported that, although fatigue was a predictor of one-year survival, the global quality of life score was not [71].

\section{Colorectal cancer}

Social functioning as measured by the EORTC QLQ-C30, or health and physical subscales as measured by the Ferrans and Powers Quality of Life Index, were shown to be prognostic for survival in colorectal cancer patients. One study found that the best model for predicting survival included diarrhoea, eating disorders, restlessness, and ability to work and sleep [72]. The results from four clinical trials of 501 locally advanced and metastatic colorectal cancer patients indicated that one-year survival was 38.3\% and $72.5 \%$ for patients with global quality of life scores below and above the median, respectively [73]. Another study with a sample of 564 patients with advanced colorectal cancer in 10 countries showed that for every 10point decrease in social functioning score, as measured by the EORTC QLQ-C30, there was a 6\% increase in the likelihood of an earlier death [76]. This study was the first external validation (on an independent dataset of patients) of a previously conducted study indicating that social functioning was an independent prognostic factor 
Table 4: Studies on relationship between quality of life data and survival in patients with gastro-oesophageal cancers

\begin{tabular}{lllll}
\hline Author(s) & Year & Sample & HRQOL measure(s) & Results* \\
\hline Blazeby et al. [64] & 2000 & 89 oesophageal cancer & $\begin{array}{l}\text { EORTC QLQ-C30 + Dysphagia } \\
\text { scale of QLQ-OES24 }\end{array}$ & $\begin{array}{l}\text { Physical functioning at baseline was } \\
\text { significantly associated with survival. }\end{array}$ \\
\hline Blazeby et al. [65] & 2001 & 89 oesophageal cancer & $\begin{array}{l}\text { EORTC QLQ-C30 + Dysphagia } \\
\text { scale of QLQ-OES24 }\end{array}$ & $\begin{array}{l}\text { Physical functioning at baseline was } \\
\text { significantly associated with survival. } \\
\text { After treatment, improved emotional } \\
\text { functioning was significantly related to } \\
\text { longer survival. }\end{array}$ \\
\hline
\end{tabular}

\begin{tabular}{lll}
\hline Fang et al. [66] 2004 & $\begin{array}{l}110 \text { oesophageal squamous cell } \\
\text { cancer }\end{array} \quad$ EORTC QLQ-C30
\end{tabular}

Pretreatment physical functioning was the most significant survival predictor while QOL scores during treatment were not. After treatment dysphagia was the most significant predictor.

\begin{tabular}{|c|c|c|c|c|}
\hline Chau et al. [67] & 2004 & $\begin{array}{l}1080 \text { locally advanced or metastatic } \\
\text { oesophago-gastric cancer }\end{array}$ & EORTC QLQ-C30 & $\begin{array}{l}\text { Pretreatment physical and role } \\
\text { functioning and global QOL predicted } \\
\text { survival. }\end{array}$ \\
\hline Park et al. [68] & 2008 & I64 advanced gastric cancer & EORTC QLQ-C30 & $\begin{array}{l}\text { Social functioning was significant } \\
\text { prognostic factor for survival. }\end{array}$ \\
\hline Bergquist et al. [69] & 2008 & 96 advanced oesophageal cancer & $\begin{array}{l}\text { EORTC QLQ-C30 + QLQ- } \\
\text { OESI8 }\end{array}$ & $\begin{array}{l}\text { Physical functioning, fatigue and reflux } \\
\text { were significant prognostic of survival. }\end{array}$ \\
\hline McKernan et al. [70] & 2008 & I52 gastric or oesophageal cancer & EORTC QLQ-C30 & $\begin{array}{l}\text { Appetite loss was significantly } \\
\text { independent predictor of survival. }\end{array}$ \\
\hline Healy et al. [7I] & 2008 & I85 localized oesophageal cancer & EORTC QLQ-C30 & $\begin{array}{l}\text { Fatigue score was predictive of I-year } \\
\text { survival but global QOL data were not. }\end{array}$ \\
\hline
\end{tabular}

Abbreviations: EORTC QLQ-C30: European Organization for Research and Treatment of Cancer Quality of Life Core Questionnaire; QLQ-OESI8 (previously QLQ-OES24): EORTC Oesophageal Cancer specific Quality of Life Questionnaire; QOL: quality of life.

* All results obtained from multivariate analyses after controlling for one or more demographic and known biomedical prognostic factors.

of survival [75]. The results are shown in Table 5[24,7276].

\section{Head and neck cancer}

Since 1998, several papers [77-84] have examined the relationship between survival and health-related quality of life in head and neck cancer (Table 6). Overall, four out of the eight studies showed no clear relationship between health-related quality of life and survival in head and neck cancer. A study of 208 head and neck cancer patients reported that physical functioning, mood and global quality of life did not predict survival. However, the same study showed that patients with less than optimal cognitive functioning had a relative risk of recurrence of 1.72 $(95 \% \mathrm{CI}=1.01-2.93)$ and a relative risk of dying of 1.90 $(95 \% \mathrm{CI}=1.10-3.26)[78]$. The authors speculated that the influence of cognitive functioning on survival in these patients might be related to the use of alcohol.
In contrast, a recent study of 495 head and neck cancer patients reported that the SF-36 physical component summary score and three domains of the HNQOL (pain, eating and speech) were associated with survival [84]. A study by Fang et al. using the EORTC QLQ-C30 and EORTC QLQ-H\&N35 showed that, while changes in quality of life scores in patients with head and neck cancer during radiotherapy were not correlated with survival, baseline fatigue score was a significant predictor of survival. They reported that an increase of 10 points in the baseline fatigue score corresponded to a $17 \%$ reduction in the likelihood of survival [79].

Finally, as Mehanna et al. suggested, the relationship between health-related quality of life and survival in head and neck cancer patients is currently neither strong nor proven, although there is some association between selected psychosocial factors and long-term survival [85]. 
Table 5: Studies on relationship between quality of life data and survival in patients with colorectal cancer

\begin{tabular}{lllll}
\hline Author(s) & Year & Sample & HRQOL measure(s) & Results* \\
\hline Loprinzi et al. [24] & 1994 & III I5 advanced colorectal or lung & A designed questionnaire & $\begin{array}{l}\text { Patients' assessment of their own performance } \\
\text { status and nutritional factors such as appetite, } \\
\text { caloric intake, or overall food intake were } \\
\text { prognostic of survival. }\end{array}$ \\
\hline Earlam et al. [72] & 1996 & 50 colorectal with liver metastases & RSCL + HADS + SIP & $\begin{array}{l}\text { Diarrhea, eating, restlessness, and ability to work } \\
\text { and sleep were predictors of survival. }\end{array}$ \\
\hline Maisey et al. [73] & 2002 & $50 I$ locally advanced and metastatic & EORTC QLQ-C30 & $\begin{array}{l}\text { Baseline physical, role, social, emotional functioning, } \\
\text { global QOL and pain, nausea, dyspnea, and sleep } \\
\text { difficulties were strong independent predictors of } \\
\text { survival. }\end{array}$ \\
\hline Lis et al. [74] & 2006 & 177 colorectal & Ferrans and Powers QLI & $\begin{array}{l}\text { Health and physical subscale was predictive of } \\
\text { survival. }\end{array}$ \\
\hline Efficace et al. [75] & 2006 & 299 metastatic colorectal & EORTC QLQ-C30 & $\begin{array}{l}\text { Social functioning was a prognostic measure of } \\
\text { survival beyond a number of previously known } \\
\text { biomedical parameters. }\end{array}$
\end{tabular}

Efficace et al. [76] $2008 \quad 564$ metastatic colorectal

EORTC QLQ-C30

Social functioning was prognostic factor for survival.

Abbreviations: EORTC QLQ-C30: European Organization for Research and Treatment of Cancer Quality of Life Core Questionnaire; HADS: Hospital and Anxiety Depression Scale; QLI: Quality of Life Index; QOL: quality of life; RSCL: Rotterdam Symptom Checklist; SIP: Sickness Impact Profile.

* All results obtained from multivariate analyses after controlling for one or more demographic and known biomedical prognostic factors.

\section{Melanoma}

Early studies showed no significant relationship between survival and social and psychological factors in melanoma patients $[12,86]$. However, a number of subsequent studies indicated a significant correlation between quality of life and survival duration. Coates et al., in a study of 152 patients with metastatic melanoma, found that overall quality of life, mood, and appetite were significant predictors of survival [87]. A study of 140 patients with advanced melanoma [90] found that a score of less than 75 points in overall quality of life and physical distress symptoms, as measured by the Rotterdam Symptom Checklist (RSCL), was associated with hazard ratios of $2.31(95 \% \mathrm{CI}=1.09-4-90)$ and $1.92(95 \% \mathrm{CI}=1.10-$ 3.36), respectively. The results are summarized in Table $7[12,86-91]$.

\section{Other cancers}

Studies of the relationship between quality of life data and survival have been reported for brain, ovarian, liver, bladder and other cancer populations. The findings are presented in Table 8[44,92-114]. Except for a few studies of liver, brain and ovarian cancer patients $[44,95,112]$, most found a significant relationship between quality of life scores and survival duration in these patients. A study of 468 patients with multiple myeloma, measuring quality of life by the EORTC QLQ-C30 [94], found that at 12 months follow-up the relative risk of death for a physical functioning score of 0-20 versus a score of 80-100 was $5.63(99 \% \mathrm{CI}=2.76-11.49)$. A study of 233 patients with unresectable hepatocellular carcinoma [103] showed that the hazard ratios for worse appetite score and better physical and role functioning scores, as measured by the EORTC QLQ-C30, were 1.07, 0.91 and 0.94, respectively. However, Mauer et al. in their two studies of brain cancer $[107,108]$ argued that while classical techniques (regression analyses) showed a positive relationship between quality of life data and survival duration, more refined analyses suggested that baseline health-related quality of life scores add relatively little to clinical factors for predicting survival.

\section{Discussion}

Although a helpful review on this topic was published recently [115], the present review, to the author's best knowledge, is the first comprehensive study examining the prognostic value of quality of life data for survival time in cancer patients. The review contained 104 studies and with only a few exceptions, the results in most instances indicated that health-related quality of life data or some quality of life measures were significant predictors of survival duration.

The early studies reported here used ad hoc instruments, while more recent studies used well-validated cancer-specific quality of life questionnaires. The most recent studies 
Table 6: Studies on relationship between quality of life data and survival in patients with head and neck cancer

\begin{tabular}{|c|c|c|c|c|}
\hline Author(s) & Year & Sample & HRQOL measure(s) & Results* \\
\hline De Boer [77] & 1998 & 133 head and neck & $\begin{array}{l}\text { Self-reported psychosocial and } \\
\text { physical functioning }\end{array}$ & $\begin{array}{l}\text { Patients with higher perceived } \\
\text { physical abilities were likely to } \\
\text { survive more and less likely to } \\
\text { develop a recurrence. }\end{array}$ \\
\hline de Graeff et al. [78] & 2001 & 208 head and neck & $\begin{array}{l}\text { EORTC QLQ-C30 + QLQ- } \\
\text { H\&N35 + CES-D }\end{array}$ & $\begin{array}{l}\text { Cognitive functioning was predictor } \\
\text { of survival while physical } \\
\text { functioning; mood and global QOL } \\
\text { were not. }\end{array}$ \\
\hline Fang et al. [79] & 2004 & 102 advanced head and neck & $\begin{array}{l}\text { EORTC QLQ-C30 + EORTC } \\
\text { QLQ-H\&N35 }\end{array}$ & $\begin{array}{l}\text { Baseline fatigue was predictive of } \\
\text { survival while changes in } \mathrm{QOL} \\
\text { scores during treatment was not. }\end{array}$ \\
\hline Mehanna and Morton [80] & 2006 & 200 head and neck & AQLQ + LSS + GHQ & $\begin{array}{l}\text { QOL at diagnosis was not significant } \\
\text { predictor of survival. One year after } \\
\text { diagnosis poor life satisfaction score } \\
\text { and pain were significant predictors } \\
\text { of survival. }\end{array}$ \\
\hline Nordgren et al. [8I] & 2006 & 89 head and neck & EORTC QLQ-C30 & $\begin{array}{l}\text { Physical functioning was significant } \\
\text { predictor of survival. }\end{array}$ \\
\hline Coyne et al. [82] & 2007 & $\begin{array}{l}1093 \text { locally advanced head and } \\
\text { neck cancer }\end{array}$ & Emotional well-being (FACT-G) & $\begin{array}{l}\text { Emotional functioning was not an } \\
\text { independent predictor of survival. }\end{array}$ \\
\hline Siddiqui et al. [83] & 2008 & $\begin{array}{l}1093 \text { locally advanced head and } \\
\text { neck cancer }\end{array}$ & FACT-H\&N & $\begin{array}{l}\text { The FACT-H\&N score was } \\
\text { independently predictive of loco- } \\
\text { regional control but not overall } \\
\text { survival. }\end{array}$ \\
\hline Karvonen-Gutierrez et al. [84] & 2008 & 495 head and neck cancer & SF-36, HNQOL & $\begin{array}{l}\text { The SF- } 36 \text { physical component } \\
\text { summary score and three domains } \\
\text { of the HNQOL (pain, eating and } \\
\text { speech) were associated with } \\
\text { survival. }\end{array}$ \\
\hline
\end{tabular}

\footnotetext{
Abbreviations: AQLQ: Auckland Quality of Life Questionnaire; CES-D: Centre for Epidemiologic Studies-Depression Scale; EORTC QLQ-C30: European Organization for Research and Treatment of Cancer Quality of Life Core Questionnaire; EORTC QLQ-H\&N35: EORTC Head and Neck Cancer specific Quality of Life Questionnaire; FACT-G: Functional Assessment of Cancer Therapy-General module; FACT-H\&N: Functional Assessment of Cancer Therapy-Head \& Neck module; HNQOL: Head and Neck Quality of Life Questionnaire; GHQ: General Health Questionnaire; LSS: Life Satisfaction Score; QOL: quality of life; SF-36: 36-item Short Form Health Survey

* All results obtained from multivariate analyses after controlling for one or more demographic and known biomedical prognostic factors.
}

supplemented their assessments with site-specific questionnaires. Overall, 59 different instruments have been used to measure quality of life in cancer patients [Additional file 1]. The EORTC QLQ-C30 was found to be the most widely used cancer-specific instrument, and as the tables in this review show, the questionnaire often gave fairly consistent and reliable results. In addition, the supplementary EORTC quality of life modules, such as QLQBR23, QLQ-LC13 and QLQ-BN20, proved very useful instruments for analysing prognostic indicators, provided that other methodological requisites were ensured. Such instruments could even capture information important to the patients and thus provide better prognostic profiles, enabling clinicians to manage cancer patients more effec- tively. However, with regard to instruments listed in the tables, one should note that some of them were used for a tailor-specific study, treatment or trial such as the Daily Diary Card (DDC) and the Auckland Quality of Life Questionnaire. Evidently some instruments were well-known generic measures, such as the SF-36, a psychological instrument such the Hospital Anxiety and Depression Scale (HADS), and the General Health questionnaire (GHQ), and/or symptom measures such the Brief Pain Inventory (BPI), and the Symptom Distress Scale (SDS). Therefore the information given in the tables was simply to reflect the variance that existed in the instruments used and neither to convey their psychometric validity nor indicate that they were cancer-specific. As such, the results 
Table 7: Studies on relationship between quality of life data and survival in patients with melanoma

\begin{tabular}{|c|c|c|c|c|}
\hline Author(s) & Year & Sample & HRQOL measure(s) & Results* \\
\hline Cassileth et al. $[12,86]$ & 1985 and 1988 & $\begin{array}{l}359 \text { unresectable cancers or } \\
\text { early stage melanoma or } \\
\text { breast cancer }\end{array}$ & Social and psychological factors & $\begin{array}{l}\text { Social and psychological factors } \\
\text { individually or in combined did } \\
\text { not influence the length of } \\
\text { survival. }\end{array}$ \\
\hline Coates et al. [87] & 1993 & I52 metastatic melanoma & LASA scales + Spitzer QLI & $\begin{array}{l}\text { QLI and LASA scores for mood, } \\
\text { appetite, and overall QOL were } \\
\text { significant predictors of survival. }\end{array}$ \\
\hline Butow et al. [88] & 1999 & I 25 metastatic melanoma & $\begin{array}{l}\text { Cognitive appraisal of threat }+ \\
\text { coping }+ \text { psychological } \\
\text { adjustment }+ \text { perceived aim of } \\
\text { treatment }+ \text { social support }+ \\
\text { QOL }\end{array}$ & $\begin{array}{l}\text { Perceived aim of treatment, } \\
\text { minimization, anger and better } \\
\text { QOL were independently } \\
\text { predictive of longer survival. }\end{array}$ \\
\hline Brown et al. [89] & 2000 & 426 early stage melanoma & $\begin{array}{l}3 \text { single-item LASA scales } \\
\text { measuring physical well-being, } \\
\text { mood and perceived effort to } \\
\text { cope }\end{array}$ & $\begin{array}{l}\text { Shorter survival duration was } \\
\text { associated with a positive mood } \\
\text { (On average patients who } \\
\text { relapsed or died reported using } \\
\text { more active, distraction or } \\
\text { avoidant styles of coping). }\end{array}$ \\
\hline Chiarion-Sileni et al. [90] & 2003 & I 40 advanced melanoma & RSCL & $\begin{array}{l}\text { Baseline overall QOL and the } \\
\text { physical symptom distress scores } \\
\text { were significant independent } \\
\text { prognostic factors for survival. }\end{array}$ \\
\hline Lehto et al. [9।] & 2007 & 59 localized melanoma & $\begin{array}{l}\text { Coping with cancer + anger } \\
\text { expression + perceived social } \\
\text { support + life stresses + domains } \\
\text { of QOL }\end{array}$ & $\begin{array}{l}\text { Anger non-expression, } \\
\text { hopelessness, over-positive } \\
\text { reporting of QOL reduced } \\
\text { survival while denial/minimizing } \\
\text { response to the diagnosis as such } \\
\text { predicted longer survival. }\end{array}$ \\
\hline
\end{tabular}

\footnotetext{
Abbreviations: LASA: Linear Analog Self Assessment; QLI; Quality of Life Index; QOL: quality of life; RSCL: Rotterdam Symptom Checklist
} * All results obtained from multivariate analyses after controlling for one or more demographic and known biomedical prognostic factors.

from studies that used ad hoc instruments, a study-specific questionnaire or only general measures should be interpreted with caution.

Many studies reported that the global or the overall quality of life was a significant independent predictor of survival. Global quality of life is a straightforward measure, asking people to evaluate their own health status or quality of life individually (or in combination). It is argued that measures such as global quality of life are patientrated and thus have the potential to reflect the patient's well-being better than a physician's observed indicators. However, it has (for instance) been recommended that since the global quality of life scale of the EORTC QLQC30 is highly correlated with other scales, it should not be included in prognostic indicator analyses when other variables from the EORTC QLQ-C30 are used, in order to achieve model stability [116]. This might explain why a recent review on the association of psychosocial factors with survival in head and neck cancer found that the base- line overall quality of life and depression were not predictors of survival [85]. In addition, when quality of life is included in prognostic indicator analyses, pre-treatment (baseline) and follow-up assessments should be distinguished. Furthermore, the relationship between baseline health-related quality of life data and survival refers to disease-specific characteristics, while follow-up healthrelated quality of life data and survival in addition refer to treatment-specific characteristics. Indeed baseline data are more often reported to be prognostic because they are more straightforward to assess. However, collecting follow-up data is a major challenge and should be encouraged, since pre-treatment quality of life data were not prognostic for survival times in some cancers, while changes in quality of life scores or follow-up data were usually prognostic in these occasions. More importantly, tumour type and stage of disease are essential for drawing conclusions from such findings. In many studies, quality of life data were prognostic indicators of survival duration 
Table 8: Studies on relationship between quality of life data and survival in patients with other cancers

\begin{tabular}{|c|c|c|c|c|}
\hline Author(s) & Year & Sample & HRQOL measure(s) & Results* \\
\hline $\begin{array}{l}\text { Andrykowski et } \\
\text { al. [92] }\end{array}$ & 1994 & 42 leukemia & $\begin{array}{l}\text { Depressed mood + Functional QOL + } \\
\text { MAC }\end{array}$ & $\begin{array}{l}\text { Anxious preoccupation and functional QOL } \\
\text { were independent predictors of survival. }\end{array}$ \\
\hline $\begin{array}{l}\text { Tannock et al. } \\
\text { [93] }\end{array}$ & 1996 & $\begin{array}{l}\text { I6I symptomatic } \\
\text { hormone-resistant } \\
\text { prostate }\end{array}$ & $\begin{array}{l}\text { EORTC QLQ-C30 + QLQ-PR25 + } \\
\text { PROSQOLI }\end{array}$ & $\begin{array}{l}\text { Appetite loss, pain, and physical functioning } \\
\text { were associated with survival. }\end{array}$ \\
\hline $\begin{array}{l}\text { Wisloff and } \\
\text { Hjorth [94] }\end{array}$ & 1997 & 468 multiple myeloma & EORTC QLQ-C30 & $\begin{array}{l}\text { Physical functioning was independent } \\
\text { prognostic factor of survival. }\end{array}$ \\
\hline $\begin{array}{l}\text { Meyers et al. } \\
{[95]}\end{array}$ & 2000 & $\begin{array}{l}80 \text { brain (recurrent } \\
\text { glioblastoma multiforme } \\
\text { or anaplastic astrocytoma) }\end{array}$ & $F A C T-B r+A D L$ & $\begin{array}{l}\text { Measures of } \mathrm{QOL} \text { and } \mathrm{ADL} \text { were not } \\
\text { independently related to survival. }\end{array}$ \\
\hline $\begin{array}{l}\text { Jerkeman et al. } \\
{[96]}\end{array}$ & 2001 & 95 aggressive lymphoma & EORTC QLQ-C30 & $\begin{array}{l}\text { Pretreatment global QOL was an } \\
\text { independent prognostic marker of overall } \\
\text { survival. }\end{array}$ \\
\hline $\begin{array}{l}\text { Roychowdury } \\
\text { et al. [97] }\end{array}$ & 2003 & $\begin{array}{l}364 \text { locally advanced and } \\
\text { metastatic bladder }\end{array}$ & EORTC QLQ-C30 & $\begin{array}{l}\text { Longer survival was associated with high } \\
\text { physical functioning, low role functioning and } \\
\text { no anorexia. }\end{array}$ \\
\hline $\begin{array}{l}\text { Sehlen et al. } \\
{[98]}\end{array}$ & 2003 & 153 brain tumors & FACT-G & $\begin{array}{l}\text { The FACT-G sum score was a significant } \\
\text { predictor of survival. }\end{array}$ \\
\hline $\begin{array}{l}\text { Collette et al. } \\
\text { [99] }\end{array}$ & 2004 & $\begin{array}{l}391 \text { symptomatic } \\
\text { metastatic hormone- } \\
\text { resistant prostate cancer }\end{array}$ & EORTC QLQ-C30 & $\begin{array}{l}\text { Insomnia and appetite loss were significant } \\
\text { independent predictors of survival. }\end{array}$ \\
\hline $\begin{array}{l}\text { Monk et al. } \\
{[100]}\end{array}$ & 2005 & $\begin{array}{l}179 \text { advanced cancer of } \\
\text { cervix }\end{array}$ & $\begin{array}{l}\text { FACT-G + Cervix subscale + FACT/GOG- } \\
\text { Ntx+ BPI }\end{array}$ & $\begin{array}{l}\text { Baseline FACT-Cx (FACT-G + Cervix } \\
\text { subscale) scores was associated with survival. }\end{array}$ \\
\hline $\begin{array}{l}\text { Brown et al. } \\
{[101]}\end{array}$ & 2005 & $\begin{array}{l}273 \text { brain } \\
\text { (high grade gloima) }\end{array}$ & $\begin{array}{l}\text { LASA scales (to measure overall QOL)+ } \\
\text { FACT-Br + Fatigue (SDS) + Sleep (ESS) + } \\
\text { depression (POMS-SF)+ Mental health } \\
\text { (MMSE) }\end{array}$ & $\begin{array}{l}\text { Changes in } \mathrm{QOL} \text { measures over time were } \\
\text { not found to be associated with survival. }\end{array}$ \\
\hline
\end{tabular}

Brown et al. 2006194 brain $\quad$ LASA scales (to measure overall QOL)+ Fatigue was significant independent predictor

[102] (high grade glioma)

FACT-Br + Fatigue (SDS) + Sleep (ESS) + depression (POMS-SF) + Mental health (MMSE)

\begin{tabular}{lllll}
\hline Yeo et al. [103] & 2006 & $\begin{array}{l}233 \text { unresectable } \\
\text { hepatocellular }\end{array}$ & EORTC QLQ-C30 & $\begin{array}{l}\text { Appetite loss, physical and role functioning } \\
\text { scores were significant predictor of survival. }\end{array}$ \\
\hline Lis et al. [104] & 2006 & 55 pancreatic cancer & Ferrans and Powers QLI & $\begin{array}{l}\text { Health and physical subscale was marginally } \\
\text { significant predictor of survival. }\end{array}$ \\
\hline $\begin{array}{l}\text { Dubois et al. } \\
\text { [105] }\end{array}$ & 2006 & $\begin{array}{l}202 \text { refractory multiple } \\
\text { myeloma }\end{array}$ & $\begin{array}{l}\text { EORTC QLQ-C30 + QLQ-MY24 + FACIT- } \\
\text { F + FACT/GOG-Ntx }\end{array}$ & Fatigue was significant predictor of survival. \\
\hline $\begin{array}{l}\text { Sullivan et al. } \\
\text { [106] }\end{array}$ & 2006 & $\begin{array}{l}809 \text { metastatic hormon- } \\
\text { refractory prostate }\end{array}$ & EORTC QLQ-C30 + FACT-P & $\begin{array}{l}\text { Baseline QOL scores (global QOL, physical, } \\
\text { role, and social functioning and pain, fatigue } \\
\text { and appetite loss) were significant predictors } \\
\text { of survival. }\end{array}$ \\
\hline $\begin{array}{l}\text { Mauer et al. } \\
\text { [107] }\end{array}$ & 2007 & $\begin{array}{l}247 \text { brain } \\
\text { (anaplastic } \\
\text { oligodenroglimas) }\end{array}$ & EORTC QLQ-C30 + EORTC QLQ-BN20 & $\begin{array}{l}\text { Emotional functioning, communication } \\
\text { deficit, future uncertainty, and weakness of } \\
\text { legs were significant prognostic of survival. } \\
\text { Baseline QOL scores added little to clinical } \\
\text { factors to predict survival. }\end{array}$
\end{tabular}
of survival.

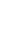

Fatigue was significant independent predictor 
Table 8: Studies on relationship between quality of life data and survival in patients with other cancers (Continued)

\begin{tabular}{|c|c|c|c|c|}
\hline $\begin{array}{l}\text { Mauer et al. } \\
{[108]}\end{array}$ & 2007 & $\begin{array}{l}490 \text { brain } \\
\text { (new diagnosed } \\
\text { glioblastoma) }\end{array}$ & EORTC QLQ-C30 + QLQ-BN20 & $\begin{array}{l}\text { Cognitive functioning, global health status, } \\
\text { and social functioning were significant } \\
\text { prognostic factors of survival. Baseline QOL } \\
\text { scores added little to clinical factors to } \\
\text { predict survival. }\end{array}$ \\
\hline
\end{tabular}

Fielding and $2007 \quad 358$ liver and lung $\quad$ FACT-G

Wong [44] $2007 \quad 358$ liver and lung

Global QOL scores did not predict survival in liver and lung cancer. Physical well-being and appetite predicted survival in lung cancer. $\begin{array}{lll}\text { Viala et al. [109] } 2007202 \text { multiple myeloma } & \begin{array}{l}\text { EORTC QLQ-C30, EORTC QLQ-MY24, } \\ \text { FACIT-F, FACT/GOG-Ntx }\end{array}\end{array}$
14 out of 21 patient-reported outcomes were significant predictors of mortality. Clinical plus PRO data increased the predictive power.

\begin{tabular}{|c|c|c|c|c|}
\hline $\begin{array}{l}\text { Bonnetain et al. } \\
\text { [1 I } 0]\end{array}$ & 2008 & $\begin{array}{l}538 \text { advanced } \\
\text { hepatocellular carcinoma }\end{array}$ & Spitzer QLI & $\begin{array}{l}\text { Baseline QOL was independent prognostic } \\
\text { factor for survival. }\end{array}$ \\
\hline $\begin{array}{l}\text { Carey et al. } \\
{[1111]}\end{array}$ & 2008 & $\begin{array}{l}244 \text { advanced ovarian } \\
\text { cancer }\end{array}$ & EORTC QLQ-C30 & $\begin{array}{l}\text { Performance status and global QOL scores } \\
\text { at baseline were prognostic factors for both } \\
\text { progression-free survival and overall survival. }\end{array}$ \\
\hline $\begin{array}{l}\text { Gupta et al. } \\
{\left[\begin{array}{ll}1 & 12\end{array}\right.}\end{array}$ & 2008 & 90 ovarian cancer & Ferrans and Powers QLI & $\begin{array}{l}\text { No statistically significant prognostic } \\
\text { association of patient satisfaction with QOL } \\
\text { was observed with survival. }\end{array}$ \\
\hline $\begin{array}{l}\text { Robinson et al. } \\
{[113]}\end{array}$ & 2008 & 86 pancreatic cancer & FACIT-F+ FAACT + BPI + SF-36 & Fatigue strongly predicted survival. \\
\hline $\begin{array}{l}\text { Strasser- } \\
\text { Weippl and } \\
\text { Ludwig [ }\left[\begin{array}{ll}\mid & 4\end{array}\right.\end{array}$ & 2008 & 92 multiple myeloma & EORTC QLQ-C30 & $\begin{array}{l}\text { Role, emotional, cognitive and social } \\
\text { functioning but not physical functioning and } \\
\text { global QOL were found to be independent } \\
\text { prognostic factors of overall survival. }\end{array}$ \\
\hline
\end{tabular}

Abbreviations: ADL: Activities of Daily Living; BPI: Brief Pain Inventory; EORTC QLQ-C30: European Organization for Research and Treatment of Cancer Quality of Life Core Questionnaire; EORTC QLQ-BN20: EORTC Brain Cancer specific Quality of Life Questionnaire; EORTC QLQMY24: EORTC Myeloma specific Quality of Life Questionnaire; EORTC QLQ-PR25: EORTC Prostate Cancer specific Quality of Life Questionnaire; ESS: Epworth Sleepiness Scale; FACIT-F: Functional Assessment of Chronic Illness Therapy-Fatigue scale; FACT-Br: Functional Assessment of Cancer Therapy-Brain module; FACT-G: Functional Assessment of Cancer Therapy-General module; FACT-P: Functional Assessment of Chronic Illness Therapy-Prostate module; FAACT: Functional Assessment of Anorexia/Cachexia Therapy; FACT/GOG-Ntx: FACT Gynecologic Oncology Group Neurotoxicity scale; LASA: Linear Analog Self Assessment; MAC: Mental Adjustment to Cancer Scale; MMSE: Folstein Mini-Mental State Examination; POMS-SF: Profile of Mood State-Short Form; PRO: patient-reported outcomes; PROSQOL: Prostate Cancer-Specific Quality-of-Life Instrument; QLI: Quality of Life Index; QOL: quality of life; SDS: Symptom Distress Scale; SF-36: 36-item Short Form Health Survey

* All results obtained from multivariate analyses after controlling for one or more demographic and known biomedical prognostic factors.

in patients with solid tumours and advanced diseases, but not in those with soft tumours and early-stage diseases.

Several measures, such as physical functioning, showed particularly significant associations with survival duration in cancer patients. It is argued that physical functioning might be a surrogate marker for an unrecognized biological prognostic indicator, so a causal association between physical functioning and survival time should not be inferred [65]. In addition, it is argued that since performance status and physical functioning are significantly associated with each other, in many instances when one includes both physical functioning and performance status in the regression models, the likelihood of finding inconsistent results can be expected. In other words, in such circumstances in some studies physical functioning would emerge as an independent prognostic factor and in some others performance status or even in certain cases both might be found prognostic factors for survival duration. Thus, as indicated earlier, the role of physical functioning and performance status in prognostic studies need to be evaluated with caution. A recent meta-analysis of the relationship between baseline quality of life data from the EORTC clinical trials and survival indicated that physical functioning was a significant independent prognostic factor but performance status (as measured by the World Health Organisation performance status) was not [5], whereas a study in metastatic kidney cancer patients reported that both physical functioning and performance 
status were correlated with a longer progression-free survival [117].

Among symptoms, appetite loss, pain and fatigue at baseline were the most important or strongest independent predictors of survival in many of the studies on different cancer populations. One possible explanation is that these symptoms are very sensitive markers of patient wellbeing. In addition, as explained by Efficace et al. [58], such findings might arise because quality of life measures in effect mask each other in multivariate analyses, so making variables such as appetite loss or pain or fatigue appear to be the most important or strongest predictors of survival time. Another possible explanation is that such symptoms might reflect, for instance, weight loss, which itself is an important prognostic indicator.

As suggested by Gotay et al. [115], there are several explanations for the association between health-related quality of life data and survival duration in cancer outcome studies. They summarized four possible explanations: (i) quality of life measures include different items and thus provide more sensitive information than traditional performance status and toxicity measures; (ii) quality of life data especially those collected at baseline before disease progression could pick up relevant information earlier than established clinical prognostic factors; (iii) quality of life data are markers of patients' behaviour because they relate to diagnosis, treatment and subsequent outcomes of the disease; and (iv) quality of life data are markers of individual characteristics such as personality style and adapting coping strategies, which affect the disease process and outcomes in cancer patients.

In addition, the relationship between measures such as global quality of life or self-rated health and survival or mortality might be explained in the context of the bodymind relationship [118-120]. For instance, a recent publication on the topic concluded that self-reported health is a unique indicator of human health status; its origins lie in a process whereby information from the individual's body and mind is received, selected, reviewed and summarized and therefore it could predict the most absolute biological events, such as survival or death [121].

The current review, however, suggests an additional explanation that might be helpful in interpreting the findings from studies of the relationship between quality of life data and survival duration. Quality of life data might be markers of the socio-economic status of cancer patients. Evidence for a relationship between socio-economic status and survival time for many cancers is being compiled [e.g. see [122-130]]. In this context, a cancer patient's socio-economic status predicts survival. For instance, cancer patients with higher social class would have a better quality of life [e.g. see [131-134]], and consequently those who report a better quality of life at baseline assessment may live longer. Thus it is not surprising that, in addition to clinical measures, quality of life data are predictive of survival duration. This hypothesis needs further assessment. In future studies on the relationship between quality of life data and survival duration, in addition to biomedical measures, adjustments should be made for patients' socioeconomic status. It would then remains to be seen whether health-related quality of life data still act as significant independent predictors of survival or not. However, the known clinical measures that most studies frequently entered into a multivariate model included age at diagnosis; gender (where necessary); stage (tumour characteristics); occurrence of metastases (or number of metastatic sites involved); weight loss; laboratory parameters (where necessary); performance status and type of treatment. It seems that co-morbidity, and measures of patients' socioeconomic status (for example income, education, occupation, living conditions or social class) are also important to be included in the final model when one considers assessing the relationship between quality of life data and survival duration.

Although this review has included studies that examined the relationship between quality of life data and survival, it excluded purely psychological studies. There are several useful studies on association between psychological data and survival and thus if one wishes to have a better understanding on the topic it is necessary to review these papers as well. For instance, a systematic review of the literature clearly documented the influence of psychological coping on survival and recurrence in cancer patients [135]. The review concluded that there is little consistent evidence that psychological coping style is important in survival from or recurrence of cancer. Similarly, a systematic review of the effect of psychosocial factors on breast cancer outcome indicated that, although most studies on the topic have shown a significant relationship between psychosocial factors and survival, the relevant psychosocial variables were neither consistently measured across studies nor, in many cases, consistent in their findings [136]. In contrast, a recent review on the relationship between stress-related psychosocial factors and survival in cancer patients indicated that stressful life experiences were related to poorer cancer survival and higher mortality. It also suggested that stress-prone personalities or unfavourable coping styles, and negative emotional responses or poor quality of life, were related to poorer cancer survival and higher mortality [137]. However, some papers that belonged in principle to the discipline of psychology were inevitably included in the present review. These papers usually reported that a measure of quality of life had been incorporated in the study, but no well-known instruments were used for the measurements. Contrary to expectation, 
these papers found that, in multivariate analyses, conditions such as over-positive reporting of quality of life [91] or having a better appetite were indicators of shorter survival

Finally, the inherent limitations and controversial issues related to studies of relationship between survival and quality of life data should not be neglected. For example, many studies reporting on a positive relationship between survival and quality of life data originate from previously conducted randomised clinical trials. Although this is the best-known methodology to evaluate treatments outcomes, it can also be argued that, since patients in randomised clinical trials have highly selected criteria (e.g. no associated co-morbidity), one might wonder whether this association also works in the real world [10]. Perhaps only by testing this hypothesis in an observational setting would it be possible to actually verify whether healthrelated quality of life parameters have a prognostic value. In addition, since most evidence on positive relationship between quality of life data and survival comes from studies with different patients groups, or studies that used different instruments to measure quality of life, or studies that applied different statistical methodology (and sometimes even inappropriate statistical analysis), thus crossstudy comparisons are impossible or very complicated, indicating that current evidence is still inconclusive [138]. With regard to statistical analysis, it is argued that statistical methodology is crucial in prognostic factor analysis of health-related quality of life where different statistical strategies can lead to different findings. Mauer et al. suggest at least two recommendations to increase a substantial accuracy of the prognostic models for relationship between quality of life data and survival: validation strategy, and added prognostic value of health-related quality of life factors analysis. They refer to the former as the only way to avoid over-fitting logistic regression models. These are regression model that are too dependent on the data set at hand, making its value on new data doubtful. The latter strategy, however, refers to computing predictive accuracy of the final model (including health-related quality of life data and known clinical prognostic factors) and comparing it with the predictive accuracy of the model with known clinical prognostic factors only, using for instance, C-indexes [138]. More technical details of Mauer et al. arguments and recommendations can be found elsewhere [139].

This review included all major search engines in combination with a manual search. However, since the strategy was based on keywords in the titles of English language publications, there is a risk that some relevant papers were missed. Furthermore, individual reports were not examined in detail, and so the findings are not all-inclusive. Bottomley and Efficace have also remarked in their edito- rial comments that it seems necessary to stress that studies on the relationship between quality of life data and survival duration have yielded considerable evidence, but this is still a relatively novel area of research in oncology and has a long way to go. They suggested that more hypothesis-driven prospective studies are needed to provide robust evidence that health-related quality of life data and patient-reported outcomes independently predict survival duration [140].

\section{Conclusion}

The studies reported in this review provide evidence for a positive relationship between quality of life data, or some aspects of quality of life measures, and the duration of survival in cancer patients. Pre-treatment (baseline) quality of life data appeared to provide the most reliable information for helping clinicians to establish prognostic criteria for treating their cancer patients. It is recommended that future studies should use valid instruments, apply sound methodological approaches and adequate multivariate statistical analyses, adjusted for socio-demographic characteristics and known clinical prognostic factors with a satisfactory validation strategy. This strategy is likely to yield more accurate and specific quality of life-related prognostic variables for specific cancers.

\section{Competing interests}

The author declares that they have no competing interests.

\section{Authors' contributions}

The author carried out this review and wrote the manuscript, and prepared all the tables and the figure.

\section{Additional material}

\section{Additional file 1}

Quality of life instruments. This is an alphabetic list of instruments used in studies of the relationship between quality of life data and survival duration in cancer patients.

Click here for file

[http://www.biomedcentral.com/content/supplementary/14777525-7-102-S1.DOC]

\section{Acknowledgements}

The author wishes to thanks Mrs. T. Rostami and Mrs. S. Fathian and A. Asadi for their secretarial assistance. This was a piece of pure academic research work and the author did not receive any financial support or grant for the study. The author also is very grateful to both anonymous referees who reviewed the manuscript. Their comments and suggestions improved the paper substantially.

\section{References}

I. Coons SJ: Health-related quality of life: let's measure and report it appropriately. Clinical Therapeutics 2007, 29:2746-2747. 
2. Montazeri A, Milroy R, Hole D, McEwen J, Gillis CR: How quality of life data contribute to our understanding of cancer patients' experiences? A study of patients with lung cancer. Qual Life Res 2003, I 2:157-166.

3. Montazeri A: Health-related quality of life in breast cancer patients: a bibliographic of the literature from 1974 to 2007. J Exp Clin Cancer Res 2008, 27:32.

4. Trask PC, Hsu MA, McQuellon R: Other paradigms: healthrelated quality of life as a measure in cancer treatment: its importance and relevance. Cancer J 2009, 15:435-440.

5. Quinten C, Coens C, Mauer M, Comte S, Sprangers MA, Cleeland C, Osoba D, Bjordal K, Bottomley A, EORTC Clinical Groups: Baseline quality of life as a prognostic indicator of survival: a metaanalysis of individual patient data from EORTC clinical trials. Lancet Oncol 2009, 10:865-871.

6. Grande GE, Farquhar MC, Barclay SI, Todd CJ: Quality of life measures (EORTC QLQ-C30 and SF-36) as predictors of survival in palliative colorectal and lung cancer patients. Palliat Support Care 2009, 7:289-297.

7. van Heijl M, Sprangers MA, de Boer AG, Lagarde SM, Reitsma HB, Busch OR, Tilanus HW, van Lanschot JJ, van Berge Henegouwen MI: Preoperative and early postoperative quality of life predict survival in potentially curable patients with esophageal cancer. Ann Surg Oncol in press.

8. US Food and Drug Administration: Guidance for industry on patient-reported outcome measures: use in medical product development to support labeling claims. [http://www.fda.gov/ ohrms/dockets/dockets/06d0044/06d0044.htm].

9. Efficace F, Kemmler G, Vignetti M, Mandelli F, Molica S, Holzner B: Health-related quality of life assessment and reported outcomes in leukaemia randomized controlled trials: a systematic review to evaluate the added value in supporting clinical decision making. Eur J Cancer 2008, 44: I497-1506.

10. Efficace F, Vignetti M, Mandelli F: Asking patients with hematological malignancies: 'how do you fee?' Does it really provide independent prognostic information for survival? Eur $J$ Haematol 2009, 82:484-485.

II. Pater JL, Loeb M: Non-anatomic prognostic factors in carcinoma of the lung: a multivariate analysis. Cancer 1982, 50:326-331.

12. Cassileth BR, Lusk EJ, Miller DS, Brown LL, Miller C: Psychosocial correlates of survival in advanced malignant disease? N Engl J Med 1985, 3 I 2: 155|-555.

13. Coates A, Gebski V, Bishop JF, Jeal PN, Woods RL, Snyder R, Tattersall MH, Byrne M, Harvey V, Gill G: Improving the quality of life during chemotherapy for advanced breast cancer. A comparison of intermittent and continuous treatment strategy. N Engl J Med 1987, 3 I 7: 1490- | 495.

14. Kaasa S, Mastekaasa A, Lund E: Prognostic factors for patients with inoperable non-small cell lung cancer, limited disease. The importance of patients' subjective experience of disease and psychosocial well-being. Radiother Oncol 1989, 15:235-242.

15. Degner L, Sloan J: Symptom distress in newly diagnosed ambulatory cancer patients and as a predictor of survival in lung cancer. J Pain Symptom Manage 1995, 10:423-431.

16. Ringdal Gl, Götestam KG, Kaasa S, Kvinnsland S, Ringdal K: Prognostic factors and survival in a heterogeneous sample of cancer patients. BrJ Cancer 1996, 73:1594-1599.

17. Tamburini M, Brunelli C, Rosso S, Ventafridda V: Prognostic value of quality of life scores in terminal cancer patients. J Pain Symptom Manage 1996, I I:32-341.

18. Coates A, Porzsolt F, Osoba D: Quality of life in oncology practice: prognostic value of EORTC QLQ-C30 scores in patients with advanced malignancy. Eur J Cancer 1997, 33:1025-1030.

19. Dancey J, Zee B, Osoba D, Whitehead M, Lu F, Kaizer L, Latreille J, Pater JL: Quality of life scores: an independent prognostic variable in a general population of cancer patients receiving chemotherapy. The National Cancer Institute of Canada Clinical Trials Group. Qual Life Res 1997, 6:151-158.

20. Chang VT, Thaler HT, Polyak TA, Kornblith AB, Lepore JM, Portenoy RK: Quality of life and survival: the role of multidimensional symptom assessment. Cancer 1998, 83:173-179.

21. Lam PT, Leung MW, Tse CY: Identifying prognostic factors for survival in advanced cancer patients: a prospective study. Hong Kong Med J 2007, 1 3:453-459.
22. Ganz PA, Lee JJ, Siau J: Quality of life assessment. An independent prognostic variable for survival in lung cancer. Cancer 1991, 67:3|3|-3135.

23. Ruckdeschel JC, Piantadosi S: Quality of life in lung cancer surgical adjuvant trial. Chest 1994, 106:324-328.

24. Loprinzi CL, Laurie JA, Wieand HS, Krook JE, Novotny PJ, Kugler JW, Bartel J, Law M, Bateman M, Klatt NE, et al.: Prospective evaluation of prognostic variables from patient-completed questionnaires. North Central Cancer Treatment Group. J Clin Oncol 1994, 1 2:601-607.

25. Buccheri GF, Ferrigno D, Tamburini M, Brunelli C: The patient's perception of his own quality of life might have an adjunctive prognostic significance in lung cancer. Lung Cancer 1995, 1 2:45-58.

26. Buccheri G: Depressive reactions to lung cancer are common and often followed by a poor outcome. Eur Respir J 1998, II:173-178.

27. Herndon JE, Fleishman S, Kornblith AB, Kosty M, Green MR, Holland $\mathrm{J}$ : Is quality of life predictive of the survival of patients with advanced nonsmall cell lung carcinoma? Cancer 1999, 85:333-340

28. Langendijk H, Aaronson NK, de Jong JM, ten Velde GP, Muller MJ, Wouters M: The prognostic impact of quality of life assessed with the EORTC QLQ-C30 in inoperable non-small cell lung carcinoma treated with radiotherapy. Radiother Oncol 2000, 55:19-25.

29. Burrows CM, Mathews WC, Colt HG: Predicting survival in patients with recurrent symptomatic malignant pleural effusions: an assessment of the prognostic values of physiologic, morphologic, and quality of life measures of extent of disease. Chest 2000, I I 7:73-78.

30. Montazeri A, Milroy R, Hole D, McEwen J, Gillis CR: Quality of life in lung cancer patients: as an important prognostic factor. Lung Cancer 200 I, 31:233-240.

31. Auchter RM, Scholtens D, Adak S, Wanger H, Cella DF, Mehta MP: Quality of life assessment in advanced non-small-cell lung cancer patients undergoing an accelerated radiotherapy regimen: report of ECOG study 4593. Int J Radiat Oncol Biol Phys 2001, 50: II 199-1206.

32. Moinpour CM, Lyons B, Grevstad PK, Lovato LC, Growley J, Czaplicki K, Buckner ZM, Ganz PA, Kelly K, Gandara DR: Quality of life in advanced non-small-cell lung cancer: results of a Southwest Oncology Group randomized trial. Qual Life Res 2002, II:II5-126.

33. Nakahara $Y$, Mochizuki $Y$, Miyamoto $Y$, Tanaka A, Kawamura T, Sasaki $S$, Nakahara $Y$, Katsura $Y$ : Mental state as a possible independent prognostic variable for survival in patients with advanced lung carcinoma. Cancer 2002, 94:3006-30I5.

34. Naughton MJ, Herndon JE, Shumaker SA, Miller AA, Kornblith AB, Chao D, Hollan J: The health - related quality of life and survival of small-cell lung cancer patients: Results of a companion study to CALGB 9033. Qual Life Res 2002, I I:235-248.

35. Eton DT, Fairclough D, Cella D, Yount SE, Bonomi P, Johnson DH: Early change in patient-reported health during lung cancer chemotherapy predicts clinical outcomes beyond those predicted by baseline report: results from eastern cooperative oncology group study 5592. J Clin Oncol 2003, 21:1536-1543.

36. Dharma-Wardene M, Au HJ, Hanson J, Dupere D, Hewitt J, Feeny D: Baseline FACT-G score is a predictor of survival for advanced lung cancer. Qual Life Res 2004, 13:1209-1216.

37. Nowak AK, Stockler MR, Byrne M): Assessing quality of life during chemotherapy for pleural mesothelioma: feasibility, validity, and results of using the European Organization for Research and Treatment of Cancer Core Quality of Life Questionnaire and Lung Cancer Module. J Clin Oncol 2004, 22:3172-3180.

38. Maione P, Perrone F, Gallo C, Manzione L, Piantedosi F, Barbera S, Cigolari S, Rosetti F, Piazza E, Robbiati SF, Bertetto O, Novello S, Migliorino MR, Favaretto A, Spatafora M, Ferraù F, Frontini L, Bearz A, Repetto L, Gridelli C, Barletta E, Barzelloni ML, laffaioli RV, De Maio E, Di Maio M, De Feo G, Sigoriello G, Chiodini P, Cioffi A, Guardasole V, Angelini V, Rossi A, Bilancia D, Germano D, Lamberti A, Pontillo V, Brancaccio L, Renda F, Romano F, Esani G, Gambaro A, Vinante O, Azzarello G, Clerici M, Bollina R, Belloni P, Sannicolò M, Ciuffreda L, Parello G, Cabiddu M, Sacco C, Sibau A, Porcile G, Castiglione F, Ostellino O, Monfardini S, Stefani M, Scagliotti G, Selvaggi 
G, De Marinis F, Martelli O, Gasparini G, Morabito A, Gattuso D, Colucci G, Galetta D, Giotta F, Gebbia V, Borsellino N, Testa A, Malaponte E, Capuano MA, Angiolillo M, Sollitto F, Tirelli U, Spazzapan S, Adamo V, Altavilla G, Scimone A, Hopps MR, Tartamella F, lanniello GP, Tinessa V, Failla G, Bordonaro R, Gebbia N, Valerio MR, D'Aprile M, Veltri E, Tonato M, Darwish S, Romito S, Carrozza F, Barni S, Ardizzoia A, Corradini GM, Pavia G, Belli M, Colantuoni G, Galligioni E, Caffo O, Labianca R, Quadri A, Cortesi E, D'Auria G, Fava S, Calcagno A, Luporini G, Locatelli MC, Di Costanzo F, Gasperoni S, Isa L, Candido P, Gaion F, Palazzolo G, Nettis G, Annamaria A, Rinaldi M, Lopez M, Felletti R, Di Negro GB, Rossi N, Calandriello A, Maiorino L, Mattioli R, Celano A, Schiavon S, Illiano A, Raucci CA, Caruso M, Foa P, Tonini G, Curcio C, Cazzaniga M: Pretreatment quality of life and functional status assessment significantly predict survival of elderly patients with advanced non-smallcell lung cancer receiving chemotherapy: a prognostic analysis of the multicenter Italian lung cancer in the elderly study. I Clin Oncol 2005, 23:6865-6872.

39. Brown J, Thorpe H, Napp V, Fairlamb DJ, Gower NH, Milroy R, Parmar MK, Rudd RM, Spiro SG, Stephens RJ, Waller D, West P, Peake MD: Assessment of quality of life in the supportive care setting of the big lung trial in non-small-cell lung cancer. J Clin Oncol 2005, 23:7417-727.

40. Martins SJ, Ho N, Cavamura SO, Harada CM, Yamamoto CA, Takagaki TY: Lung cancer symptoms and pulse oximetry in the prognostic assessment of patients with lung cancer. BMC Cancer 2005, 5:72.

41. Efficace F, Bottomley A, Smit EF, Lianes P, Legrand C, Debruyne C, Schramel F, Smit HJ, Gaafar R, Biesma B, Manegold C, Coens C, Giaccone G, Van Meerbeeck J, the EORTC Lung Cancer Group and Quality of Life Unit: Is a patient's self-reported health-related quality of life a prognostic factor for survival in non-small-cell lung cancer patients? A multivariate analysis of prognostic factors of EORTC study 08975. Ann Oncol 2006, 17:1698-1704.

42. Sundstrøm S, Bremnes RM, Brunsvig P, Aasebø U, Kaasa S, Norwegian Lung Cancer Study Group: Palliative thoracic radiotherapy in locally advanced non-small cell lung cancer: can quality-oflife assessments help in selection of patients for short- or long-course radiotherapy? J Thorac Oncol 2006, 1:816-824.

43. Bottomley A, Coens C, Efficace F, Gaafar R, Manegold C, Burgers S, Vincent M, Legrand C, van Meerbeeck JP, EORTC-NCIC: Symptoms and patient-reported well-being: do they predict survival in malignant pleural mesothelioma? A prognostic factor analysis of EORTC-NCIC 08983: randomized phase III study of cisplatin with or without raltitrexed in patients with malignant pleural mesothelioma. J Clin Oncol 2007, 25:5770-5776.

44. Fielding R, Wong WS: Quality of life as a predictor of cancer survival among Chinese liver and lung cancer patients. Eur J Cancer 2007, 43:1723-1730.

45. Jacot $W$, Colinet $B$, Bertrand D, Lacombe S, Bozonnat MC, Daurès JP, Pujol JL, OncoLR health network: Quality of life and comorbidity score as prognostic determinants in non-small-cell lung cancer patients. Ann Oncol 2008, 19:1458-1464.

46. Coates A, Gebski V, Signorini D, Murray P, McNeil D, Byne M, Forbes JF: Prognostic value of quality of life scores during chemotherapy for advanced breast cancer. J Clin Oncol 1992, 10:1833-1838.

47. Fraser SC, Ramirez AJ, Ebbes SR, Fallowfield LJ, Dobbs HJ, Richards MA, Bates T, Baum M: A daily diary for quality of life measurement in advanced breast cancer trials. $\mathrm{Br} J$ Cancer 1993, 67:34I-346.

48. Seidman AD, Portenoy R, Yao TJ, Lepore J, Mont EK, Kortmansky J, Onetto N, Ren L, Grechko J, Beltangady M, et al:: Quality of life in phase II trials-A study of methodology and predictive value in patients with advanced breast cancer treated with paclitaxel, plus granulocyte colony stimulating factor. J Natl Cancer Inst 1995, 187:1316-1322.

49. Tross S, Herndon J, Korzun A, Kornblith AB, Cella DF, Herndon JF, Raich P, Johnson A, Kiang DT, Perloff M, Norton L, Wood W, Holland JC, From the Cancer and Leukemia Group B: Psychosocial symptoms and disease-free and overall survival in women with stage II breast cancer. J Natl Cancer Inst 1996, 88:66I-667.

50. Watson M, Haviland JS, Greer S, Davidson J, Bliss JM: Influence of psychological response on survival in breast cancer: a population-based cohort study. Lancet 1999, 16:1331-1336.
51. Coates AS, Hurny C, Peterson HF, Bernhard J, Castinglione-Gertsch M, Gelberg D, Goldhirsch A: Quality of life scores predict outcome in metastatic but not early breast cancer. J Clin Oncol 2000, I 8:3768-3774

52. Kramer JA, Curran D, Piccart M, de Haes JC, Bruning PF, Klijn JG, van Hoorebeeck I, Paridaens R: Identification and interpretation of clinical and quality of life prognostic factors for survival and response to treatment in firs-line chemotherapy in advanced breast cancer. Eur J Cancer 2000, 36:1498-1506.

53. Shimozuma K, Sonoo H, Ichihara K, Tanaka K: The prognostic value of quality of life scores: preliminary results of an analysis of patients with breast cancer. Surg Today 2000, 30:255-26I.

54. Butow PN, Coates AS, Dunn SM: Psychosocial predictors of survival: metastatic breast cancer. Ann Oncol 2000, I I:469-474.

55. Luoma ML, Hakamies-Blomqvist L, Sjostrom J, Pluzanska A, Ottoson $\mathrm{S}$, Mouridsen H, Bengtsson NO, Bergh J, Malmstrom P, Valvere V, Tennvall L, Blomqvist C: Prognostic value of quality of life scores for time to progression (TTP) and overall survival time (OS) in advanced breast cancer. Eur J Cancer 2003, 39:1370-1376.

56. Winer EP, Berry DA, Woolf S, Duggan D, Kornblith A, Harris LN, Michaelson RA, Kirshner JA, Fleming GF, Perry MC, Graham ML, Sharp SA, Keresztes R, Henderson IC, Hudis C, Muss H, Norton L: Failure of higher-dose paclitaxel to improve outcome in patients with metastatic breast cancer: cancer and leukemia group B trial 9342. J Clin Oncol 2004, 22:206I-2068.

57. Efficace F, Therasse P, Piccart MJ, Coens C, van Steen K, WelnickaJaskiewicz M, Cufer T, Dyczka J, Lichinitser M, Shepherd L, de Haes $H$, Sprangers MA, Bottomley A: Health-related quality of life parameters as prognostic factors in a nonmetastatic breast cancer population: an international multicenter study. J Clin Oncol 2004, 22:338I-3388.

58. Efficace F, Biganzoli L, Piccart M, Coens C, van Steen K, Cufer T, Coleman RE, Calvert HA, Gamucci T, Twelves C, Fargeot P, Bottomley $A$ : Baseline health-related quality of life data as prognostic factors in a phase III multicenter study of women with metastatic breast cancer. Eur J Cancer 2004, 40:1021-1030.

59. Goodwin PJ, Ennis M, Bordeleau LJ, Pritchard KT, Trudeau Me, Koo J, Hood N: Health-related quality of life and psychosocial status in breast cancer prognosis: analysis of multiple variables. | Clin Oncol 2004, 22:4 |84-4|92.

60. Watson M, Homewood J, Haviland J, Bliss J: Influence of psychosocial response on breast cancer survival: I0-year follow-up of a population-based cohort. European Journal of Cancer 2005, 4I:17|0-17|4.

61. Lehto US, Ojanen M, Dyba T, Aromaa A, Kellokumpu Lehtinen P: Baseline psychosocial predictors of survival in localized breast cancer. Br J Cancer 2006, 94: 1245-1252.

62. Gupta D, Granick J, Grutsch JF, Lis CG: The prognostic association of health-related quality of life scores with survival in breast cancer. Support Care Cancer 2007, 1 5:387-393.

63. Groenvold M, Petersen MA, Idler E, Bjorner JB, Fayers PM, Mouridsen $\mathrm{HT}$ : Psychosocial distress and fatigue predicted recurrence and survival in primary breast cancer patients. $\mathrm{Br} /$ Cancer 2007, 105:209-219.

64. Blazeby JM, Brookes ST, Alderson D: Prognostic value of quality of life scores in patients with oesophageal cancer. Br J Surg 2000, 87:362-373.

65. Blazeby JM, Brookes ST, Alderson D: The prpognostic value of quality of life scores during treatment for oesophageal cancer. Gut 200I, 49:227-230.

66. Fang FM, Tsai WL, Chiu HC, Kuo WR, Hsiung CY: Quality of life as a survival predictor for esophageal squamous cell carcinoma treated with radiotherapy. Int J Radiat Oncol Biol Phys 2004, 58: I394-I 404.

67. Chau I, Norman AR, Cunningham D, Waters JS, Oates J: Multivariate prognostic factor analysis in locally advanced and metastatic esophago-gastric cancer: pooled analysis from three multicenter, randomized, controlled trials using individual patient data. J Clin Oncol 2004, 22:2395-2403.

68. Park SH, Cho MS, Kim YS, Hong J, Nam E, Park J, Cho EK, Shin DB, Lee JH, Lee WK: Self-reported health-related quality of life predicts survival for patients with advanced gastric cancer treated with first-line chemotherapy. Qual Life Res 2008, I7:207-2|4.

69. Bergquist $\mathrm{H}$, Johnsson A, Hammerlid E, Wenger U, Lundell L, Ruth M: Factors predicting survival in patients with advanced 
oesophageal cancer: a prospective multicentre evaluation. Aliment Pharmacol Ther 2008, 27:385-395.

70. McKernan M, Mcmillan Dc, Anderson JR, Angerson WJ, Stuart RC: The relationship between quality of life (EORT QLQ-C30) and survival in patients with gastro-oesophageal cancer. $\mathrm{Br}$ J Cancer 2008, 98:888-893.

7I. Healy LA, Ryan AM, Moore J, Rowley S, Ravi N, Byrne PJ, Reynolds $\mathrm{JV}$ : Health-related quality of life assessment at presentation may predict complications and early relapse in patients with localized cancer of the esophagus. Dis Esophagus 2008, 21:522-528.

72. Earlam S, Glover C, Fordy C, Burke D, Allen-Mersh TG: Relation between tumor size, quality of life, and survival in patients with colorectal liver metastases. J Clin Oncol 1996, I 4: 17I-I75.

73. Maisey NR, Norman A, Watson M, Allen MJ, Hill ME, Cunningham D: Baseline quality of life predicts survival in patients with advanced colorectal cancer. Eur / Cancer 2002, 38: I35 I- I 357.

74. Lis CG, Gupta D, Granick J, Grutsch JF: Can patient satisfaction with quality of life predict survival in advanced colorectal cancer? Support Care Cancer 2006, I4: I I04-I I IO.

75. Efficace F, Bottomley A, Coens C, Van Steen K, Conroy T, Schöffski $P$, Schmoll $H$, Van Cutsem E, Köhne CH: Does a patient's selfreported health-related quality of life predict survival beyond key biomedical data in advanced colorectal cancer? Eur J Cancer 2006, 42:42-49.

76. Efficace $F$, Innominato PF, Bjarnason G, Coens $C$, Humblet $Y$, Tumolo S, Genet D, Tampellini M, Bottomley A, Garufi C, Focan C, Giacchetti S, Lévi F, Chronotherapy Group of the European Organisation for Research and Treatment of Cancer: Validation of patient's selfreported social functioning as an independent prognostic factor for survival in metastatic colorectal cancer patients: results of an international study by the Chronotherapy Group of the European Organization for Research and Treatment of Cancer. I Clin Oncol 2008, 26:2020-2026.

77. De Boer MF, Borne B Van den, Pruyn JF, Ryckman RM, Volovics L, Knegt PP, Meeuwis CA, Mesters I, Verwoerd CD: Psychosocial and physical correlates of survival and recurrence in patients with head and neck carcinoma: results of a 6-year longitudinal study. Cancer 1998, 83:2567-2579.

78. de Graeff A, de Leeuw JR, Row WJ, Hordijk GJ, Blijham GH, Winnubst JA: Sociodemographic factors and quality of life as prognostic indicators in head and neck cancer. Eur J Cancer 200 I, 37:332-339.

79. Fang FM, Liu YT, Tang Y, Wang CJ, Ko SF: Quality of life as a survival predictor for patients with advanced head and neck carcinoma treated with radiotherapy. Cancer 2004, 100:425-432.

80. Mehanna HM, Morton RP: Does quality of life predict long-term survival in head and neck cancer patients. Arch Otolaryngol Head Neck Surg 2006, 132:27-31.

81. Nordgren M, Jannert M, Boysen M, et al.: Health-related quality of life in patients with pharyngeal carcinoma: a five year followup. Head Neck 2006, 28:339-349.

82. Coyne JC, Pajak TF, Harris J, Konski A, Movsas B, Ang K, Watkins Bruner D, Radiation Therapy Oncology Group: Emotional wellbeing does not predict survival in head and neck cancer patients: a Radiation Therapy Oncology Group study. Cancer 2007, I I 0:2568-2575

83. Siddiqui F, Pajak TF, Watkins-Bruner D, Konski AA, Coyne JC, Gwede CK, Garden AS, Spencer SA, Jones C, Movsas B: Pretreatment quality of life predicts for locoregional control in head and neck cancer patients: a radiation therapy oncology group analysis. Int $J$ Radiat Oncol Biol Phys 2008, 70:353-360.

84. Karvonen-Gutierrez CA, Ronis DI, Fowler KE, Terrell JE, gruber SB, Duffy SA: Quality of life scores predict survival among patients with head and neck cancer. J Clin Oncol 2008, 26:2754-2760

85. Mehanna HM, De Boer MF, Morton RP: The association of psycho-social and survival in head and neck cancer. Clin Otolaryngol 2008, 33:83-89.

86. Cassileth BR, Walsh WP, Lusk Ej: Psychosocial correlates of cancer survival: a subsequent report 3 to 8 years after cancer diagnosis. J Clin Oncol 1988, 6:1753-1759.

87. Coates A, Thomson D, McLeod GR, Hersey P, Gill PG, Olver IN, Kefford R, Lowenthal RM, Beadle G, Walpole E: Prognostic value of quality of life scores in a trial of Chemotherapy with or with- out interferon in patients with metastatic malignant melanoma. Eur J Cancer 1993, 29:173 I-1734.

88. Butow PN, Coates AS, Dunn SM: Psychosocial predictors of survival in metastatic melanoma. J Clin Oncol 1999, 17:2256.

89. Brown JE, Butow PN, Culjak G, Coates AS, Dunn SM: Psychosocial predictors of outcome: time to relapse and survival in patients with early stage melanoma. Br J Cancer 2000, 83: $1448-1453$.

90. Chiarion-Sileni V, Del Bianco P, De Salvo GL, Lo Re G, Romanini A, Labianca R, Nortilli R, Corgna E, Dalla Palma M, Lo Presti G, Ridolfi $\mathrm{R}$, Italian Melanoma Intergroup (IMI): Quality of life evaluation in a randomized trial of chemotherapy versus bio-chemotherapy in advanced melanoma patients. Eur J Cancer 2003, 39:1577-1585.

91. Lehto US, Ojanen M, Dyba T, Aromaa A, Kellokumpu Lehtinen P: Baseline psychosocial predictors of survival in localized melanoma. J Psychosom Res 2007, 63:9-15.

92. Andrykowski MA, brady MJ, Henslee-Downey PJ: Psychosocial factors predictive of survival after allogeneic bone marrow transplantation for leukemia. Psychosom Med 1994, 56:432-439.

93. Tannock IF, Osoba D, Stockler MR, Ernst DS, Neville AJ, Moore MJ, Armitage GR, Wilson JJ, Venner PM, Coppin CM, Murphy KC: Chemotherapy with mitoxantrone plus prednisone or prednisone alone for symptomatic hormone-resistant prostate cancer: a Canadian randomized trial with palliative end points. J Clin Oncol 1996, I4:1753-1755.

94. Wisløff $F$, Hjorth M: Health-related quality of life assessed before and during chemotherapy predicts for survival in multiple myeloma. Nordic Myeloma Study Group. Br J Haematol 1997, 97:29-37.

95. Meyers CA, Hess KR, Yung WK, Levin VA: Cognitive function as predictor of survival in patients with recurrent malignant glioma. J Clin Oncol 2000, 1 8:646-650.

96. Jerkeman M, Kaasa S, Hjermstad M, Kvaløy S, Cavallin-Stahl E: Health-related quality of life and its potential prognostic implications in patients with aggressive lymphoma: a Nordic Lymphoma Group Trial. Med Oncol 200I, 18:85-94.

97. Roychowdhury DF, Hayden A, Liepa AM: Health-related qualityof-life parameters as independent prognostic factors in advanced or metastatic bladder cancer. J Clin Oncol 2003, 21:673-678.

98. Sehlen S, Lenk M, Hollenhorst H, Schymura B, Aydemir U, Herschbach P, Duhmke E: Quality of life (QoL) as predictive mediator variable for survival in patients with intracerebral neoplasma during radiotherapy. Onkologie 2003, 26:38-43.

99. Collette L, Andel GA, Bottomley A, Oosterhof G, Albrecht W, Rrijke TM: Is baseline quality of life useful for predicting survival with hormone-Refractory prostate cancer? A pooled Analysis of three studies of the European organization for research and treatment of cancer genitourinary Group. J Clin Oncol 2004, 22:3877-3885

100. Monk BJ, Huang HQ, Cella D, Long HJ, Gynecologic oncology Group study: Quality of life outcome from a randomized phase III trial of cisplatin with or without topotecan in advanced carcinoma of the cervix: a gynecologic oncology group study. J Clin Oncol 2005, 23:4617-4625.

I0I. Brown PD, Maurer MJ, Rummans TA, Pollock BE, Ballman KV, Sloan JA, Boeve BF, Arusell RM, Clark MM, Buckner JC: A prospective study of quality of life in adults with newly diagnosed highgrade gliomas: the impact of the extent of resection on quality of life and survival. Neurosurgery 2005, 57:495-504.

102. Brown PD, Ballman KV, Rummans TA, Maurer MJ, Sloan JA, Boeve BF, Gupta L, Tang-Wai DF, Arusell RM, Clark MM, Buckner JC: Prospective study of quality of life adults with newly diagnosed highgrade gliomas. J Neurooncol 2006, 76:283-291.

103. Yeo W, Mo FK, Koh J, Chan AT, Leung T, Hui P, Chan L, Tang A, Lee J], Mok TS, Lai PB, Johnson PJ, Zee B: Quality of life is predictive of survival in patients with unresectable hepatocellular carcinoma. Ann Oncol 2006, 17:1083-1089.

104. Lis CG, Gupta D, Grutsch JF: Patient satisfaction with quality of life as a predictor of survival in pancreatic cancer. Int J Gastrointest Cancer 2006, 37:35-44.

105. Dubois D, Dhawan R, velde H Van de, Esseltine D, Gupta S, Viala M, Loge C: Descriptive and prognostic value of patient-reported outcomes: the bortezomib experience in relapsed and refractory multiple myeloma. J Clin Oncol 2006, 24:976-982. 
106. Sullivan PW, Nelson JB, Mulani PM, Sleep D: Quality of life as potential predictor morbidity and mortality in patients with metastastic hormone-refractory prostate cancer. Qual Life Res 2006, I5:I297-I306.

107. Mauer ME, Taphoorn MJ, Bottomley A, Coens C, Efficace F, Sanson $M$, Brandes AA, Rijt CC van der, Bernsen HJ, Frénay M, Tijssen CC, Lacombe D, Bent MJ van den, EORTC Brain Cancer Group: Prognostic value of health-related quality-of-life data in predicting survival in patients with anaplastic oligodendrogliomas, from a phase III EORTC brain cancer group study. J Clin Oncol 2007, 25:573I-5737.

108. Mauer M, Stupp R, Taphoorn MJ, Coens C, Osoba D, Marosi C, Wong R, Witte O, Caimcross JG, Efficace F, Mirimarnoff RO, Forsyth $P$, Bent $M J$ van den, Weller M, Bottomley $A$ : The prognostic value of health-related quality-of-life data in predicting survival in glioblastoma cancer patients: results from an international randomised phase III EORTC Brain Tumour and Radiation Oncology Groups, and NCIC Clinical Trials Group study. $\mathrm{Br}$ J Cancer 2007, 97:302-307.

109. Viala M, Bhakar AL, de la Loge C, Velde $H$ van de, Esseltine D, Chang $M$, Dhawan R, Dubois D: Patient-reported outcomes helped predict survival in multiple myeloma using partial least squares analysis. I Clin Epidemiol 2007, 60:670-679.

I I0. Bonnetain F, Paoletti X, Collette S, Doffoel M, Bouché O, Raoul JL, Rougier P, Masskouri F, Barbare JC, Bedenne L: Quality of life as a prognostic factor of overall survival in patients with advanced hepatocellular carcinoma: results from two French clinical trials. Qual Life Res 2008, I 7:83 I-843.

I I I. Carey MS, Bacon M, Tu D, Butler L, Bezjak A, Stuart GC: The prognostic effects of performance status and quality of life scores on progression-free survival and overall survival in advanced ovarian cancer. Gynecol Oncol 2008, I08:100-105.

I I2. Gupta D, Grutsch JF, Lis CG: Patient satisfaction with quality of life as a prognostic indicator in ovarian cancer patients treated in an integrative treatment setting. J Soc Integr Oncol 2008, 6:98-104.

113. Robinson DW, Eisenberg DF, Cella D, Zhao N, de Boer C, De Witte $M$ : The prognostic significance of patient-reported outcomes in pancreatic cancer cachexia. J Support Oncol 2008, 6:283-290.

I 14. Strasser-Weippl K, Ludwig H: Psychosocial QOL is an independent predictor of overall survival in newly diagnosed patients with multiple myeloma. Eur J Haematol 2008, 81 :374-379.

I 15. Gotay CC, Kawamoto CT, Bottomoley A, Efficace F: The prognostic significance of patient-reported outcomes in cancer clinical trials. J Clin Oncol 2008, 26: |355-| 363.

1 16. Van Steen K, Curran D, Kramer J, Molenberghs G, Van Verckem A, Bottomley A, Sylvester R: Multicollinearity in prognostic factor analyses using the EORTC QLQ-C30: identification and impact on model selection. Stat Med 2002, 2 I:3865-3884.

I 17. Herrmann E, Gerss J, Bierer S, Kopke T, Bolenz C, Hertle L, Wulfing $\mathrm{C}$ : Pre-treatment global quality of health predicts progression free survival in metastatic kidney cancer patients treated with sorafenib or sunitinib. J Cancer Res Clin Oncol 2009, | 35:61-67.

I 18. Spiegel D: Psychosocial aspects of breast cancer treatment. Semin Oncol 1997, 24(Suppl I):S36-S47.

1 19. Gordon JS: Mind-body medicine and cancer. Hematol Oncol Clin North Am 2008, 22:683-708.

120. Littrell J: The mind-body connection: not just a theory anymore. Soc Work Health Care 2008, 46: I7-37.

121. Jylhä $M$ : What is self-rated health and why does it predict mortality? Towards a unified conceptual model. Soc Sci Med 2009, 69:307-316.

122. Harris AR, Bowley DM, Stannard A, Kurrimboccus S, Geh JI, Karandikar S: Socioeconomic deprivation adversely affects survival of patients with rectal cancer. Br J Surg 2009, 96:763-768.

123. Braaten T, Weiderpass E, Lund E: Socioeconomic differences in cancer survival: the Norwegian Women and Cancer Study. BMC Public Health 2009, 9:178.

124. Kelsall HL, Baglietto L, Muller D, Haydon AM, English DR, Giles GG: The effect of socioeconomic status on survival from colorectal cancer in the Melbourne Collaborative Cohort Study. Soc Sci Med 2009, 68:290-297.

125. Byers TE, Wolf HJ, Bauer KR, Bolick-Aldrich S, Chen VW, Finch JL, Fulton JP, Schymura MJ, Shen T, Van Heest S, Yin X, Patterns of Care Study Group: The impact of socioeconomic status on survival after cancer in the United States: findings from the National Program of Cancer Registries Patterns of Care Study. Cancer 2008, I I 3:582-59 I.

126. Ou SH, Zell JA, Ziogas A, Anton-Culver H: Low socioeconomic status is a poor prognostic factor for survival in stage I nonsmall cell lung cancer and is independent of surgical treatment, race, and marital status. Cancer 2008, I 2:20 I I-2020.

127. Gomez SL, O'Malley CD, Stroup A, Shema SJ, Satariano WA: Longitudinal, population-based study of racial/ethnic differences in colorectal cancer survival: impact of neighborhood socioeconomic status, treatment and comorbidity. BMC Cancer 2007, 7:193.

128. Shack LG, Rachet B, Brewster DH, Coleman MP: Socioeconomic inequalities in cancer survival in Scotland 1986-2000. Br J Cancer 2007, 97:999-1004.

129. Dalton SO, Ross L, Düring M, Carlsen K, Mortensen PB, Lynch J, Johansen $C$ : Influence of socioeconomic factors on survival after breast cancer--a nationwide cohort study of women diagnosed with breast cancer in Denmark 1983-1999. Int J Cancer 2007, I 2 1: 1983-1999.

130. Du XL, Meyer TE, Franzini L: Meta-analysis of racial disparities in survival in association with socioeconomic status among men and women with colon cancer. Cancer 2007, 109:2161-2170.

131. Ashing-Giwa KT, Lim JW: Examining the impact of socioeconomic status and socioecologic stress on physical and mental health quality of life among breast cancer survivors. Oncol Nurs Forum 2009, 36:79-88.

132. Demiral AN, Sen M, Demiral Y, Kinay M: The effect of socioeconomic factors on quality of life after treatment in patients with head and neck cancer. Int J Radiat Oncol Biol Phys 2008, 70:23-27

133. Bowen DJ, Alfano CM, McGregor BA, Kuniyuki A, Bernstein L, Meeske K, Baumgartner KB, Fetherolf J, Reeve BB, Smith AW, Ganz PA, McTiernan A, Barbash RB: Possible socioeconomic and ethnic disparities in quality of life in a cohort of breast cancer survivors. Breast Cancer Res Treat 2007, I 06:85-95.

134. Montazeri A, Hole DJ, Milroy R, McEwen J, Gillis CR: Quality of life in lung cancer patients: does socioeconomic status matter? Health Qual Life Outcomes 2003, I:I9.

135. Petticrew M, Bell R, Hunter D: Influence of psychological coping on survival and recurrence in people with cancer: systematic review. BMJ 2002, 325: 1066.

136. Falagas ME, Zarkadoulia EA, loannidou EN, Peppas G, Christodoulou C, Rafailidis PI: The effect of psychosocial factors on breast cancer outcome: a systematic review. Breast Cancer Res 2007, 9:R44.

137. Chida Y, Hamer M, Wardle j, Steptoe A: Do stress-related psychosocial factors contribute to cancer incidence and survival? Nat Clin Pract Oncol 2008, 5:466-475.

138. Mauer ME, Bottomley A, Coens C: Statistical methodology is crucial in prognostic factor analysis of health-related quality of life. Qual Life Res 2008, I 7: 1043-1044.

139. Mauer ME, Bottomley A, Coens C, Gotay C: Prognostic factor analysis of health-related quality of life data in cancer: a statistical methodological evaluation. Expert Rev Pharmacoecon Outcomes Res 2008, 8:179-196.

140. Bottomley A, Efficace F: Predicting survival in advanced cancer patients: is it possible with patient-reported health status data? Ann Oncol 2006, I7:1037-1038. 